NBER WORKING PAPER SERIES

\title{
BIG BUSINESS STABILITY AND ECONOMIC GROWTH: IS WHAT'S GOOD FOR GENERAL MOTORS GOOD FOR AMERICA?
}

\author{
Kathy Fogel \\ Randall Morck \\ Bernard Yeung \\ Working Paper 12394 \\ http://www.nber.org/papers/w12394 \\ NATIONAL BUREAU OF ECONOMIC RESEARCH \\ 1050 Massachusetts Avenue \\ Cambridge, MA 02138 \\ July 2006
}

We are grateful for insightful suggestions and help from Philippe Aghion, Melsa Ararat, Africa Ariño, Daron Acemoglu, Edgar Cabral, Petra Christmann, Mara Faccio, Joseph Fan, Ray Fisman, Pankaj Ghemawat, Klaus Gugler, Campbell Harvey, Peter Holgfelt, Simon Johnson, Andrew Karolyi, Tarun Khanna, E. Han Kim, Jung-Wook Kim, Bent Kromand, Larry Lang, Don Lessard, Ross Levine, Vikas Mehrotra, Joel Mokyr, Emi Nakamura, Andris Nobl, Hakan Orbay, Federica Pazzaglia, Enrico Perotti, Raghuram Rajan, Rahul Ravi, Joan Enric Ricart, Tom Scott, Andrei Shleifer, Jeremy Stein, Jan Svejnar, Steen Thomsen, Daniel Trefler, Saif Warraich, Marina Whitman, Clas Wihlborg, and Luigi Zingales. We also thank participants at the Academy of Management 2001 All Academy Symposium, Canadian Economics Association, Canadian Institute for Advanced Research Institutions, Organizations and Growth Program meeting at the University of Toronto, Copenhagen Business School, Duke University, Financial Management Association 2001 Doctoral Student Seminar, Harvard Business School, IESE Business School and Harvard Business School's 1st International Workshop on Creating Value through Global Strategy in Barcelona, Spain, Korea University's Asian Institute for Corporate Governance, Multinational Finance Association, Third Asian Corporate Governance Conference at Korea University, NBER 2002 Summer Institute in Corporate Finance, Swedish Institute of Economic Research conference at Mölle, Turkish Corporate Governance Forum, American Finance Association Meetings (2005), University of Alberta, University of Amsterdam, University of California at Berkeley, University of Toronto, Baruch University, World Bank Global Corporate Governance Forum, and Yale's International Institute of Corporate Governance. Kathy Fogel gratefully acknowledges an International Research Grant from the Western Center of Economic Research at the University of Alberta. Randall Morck gratefully acknowledges financial support from the SSHRC. The views expressed herein are those of the author(s) and do not necessarily reflect the views of the National Bureau of Economic Research.

(C2006 by Kathy Fogel, Randall Morck and Bernard Yeung. All rights reserved. Short sections of text, not to exceed two paragraphs, may be quoted without explicit permission provided that full credit, including $\odot$ notice, is given to the source. 
Big Business Stability and Economic Growth: Is What's Good for General Motors Good for America?

Kathy Fogel, Randall Morck, and Bernard Yeung

NBER Working Paper No. 12394

July 2006

JEL No. O16

\begin{abstract}
What is good for big business need not generally advance a country's overall economy. Big business turnover correlates with rising income, productivity, and (in high income countries) faster capital accumulation; consistent with Schumpeter's (1912) creative destruction and recent formalizations like Aghion and Howitt (1992). Turnover appears to "cause" growth; and disappearing behemoths, more than rising stars, drive our results. Stronger findings suggest more intense creative destruction in countries with higher incomes, as well as those with smaller governments, Common Law courts, smaller banking systems, stronger shareholder rights, and more open economies. Only the last matters more in lower income countries.
\end{abstract}

\author{
Kathy Fogel \\ College of Business \\ Northern Kentucky University \\ Highland Heights, KY 41099 \\ fogelk1@nku.edu \\ Randall Morck \\ School of Business \\ University of Alberta \\ Edmonton, Alberta \\ CANADA T6G 2R6 \\ and NBER \\ randall.morck@ualberta.ca \\ Bernard Yeung \\ Stern School of Business \\ New York University \\ New York, NY 10012 \\ byeung@stern.nyu.edu
}




\section{Big Business Stability and Economic Growth: Is What's Good for General Motors Good for America?}

\section{Introduction}

National economies have landmark corporations. Maersk shipping symbolizes Denmark's maritime history, as Nokia marks Finland's success in the "new economy." Many, often the principals of such great businesses, link an economy's fortunes to those of its landmark firms. Most famously, Charles Wilson, Chairman of the now financially shaky GM, proclaimed, "What is good for the country is good for General Motors and vice versa."

A positive link might reflect large corporations prospering because they are well managed and the wealth they create for all their stakeholders spills over to the rest of the economy. Schumpeter (1942), Romer (1986) and others argue that large, quasi-monopolistic firms create and finance the innovation that fuels economic growth. This is because large, dominant businesses can afford to innovate continuously, sustaining both their dominance and their economy's growth. Schumpeter (1942) adds that such stability provides job security, which Holmstrom (1989) argues permits high risk-high return undertakings, including investments in firm-specific human capital that would be unacceptable career risks to managers and employees in smaller firms. A positive feedback ensues, with the dominance of large businesses enhancing their stability, which further heightens their dominance. More generally, Caves (1982), D'Cruz and Rugman (2000) and others suggest large business enterprises coordinate the creation and capture of various economies of scale and scope.

But other plausible arguments link the continuous dominance of large businesses to economy stagnation. Schumpeter (1912), Aghion and Howitt (1992, 1998), Aghion et al. (1999), and others link innovation per se to the turnover of dominant businesses, making the continuous 
dominance of a cadre of great businesses a symptom of stagnation. Nelson and Winter (1982) visualize firms as collections of "routines" that develop slowly and resist change. Routines let firms prosper if they fit current economic conditions - institutional constraints, consumer preferences and production technologies. But as conditions change, upstarts with new routines displace past winners that cannot change their ways. Krueger (1974), Helpman and Grossman (2002), Rajan and Zingales (2003), Morck, Wolfenzon, and Yeung (2005), and others argue that large established firms invest political rent-seeking, manipulating their economies' institutions to lock in the status quo and block upstarts. This maintains their dominance at the expense of their economy's growth. Or, welfare maximizing governments might lock in the status quo if voters genuinely prefer slow stable growth to faster but more chaotic growth (Roe, 2003).

Despite their fundamental importance, little empirical work explores these theories. In part, this may be because they apply to what Shumpeter (1942) calls the "very long run" - time measured in generations, not years. Clear empirical tests require reliable data over a sufficiently long term for a sufficient number of economies.

This paper is a first pass at relating large business turnover to long-run growth. We measure the stability of the largest businesses in 44 countries over 1975 to 1996 . We use this period because it includes the first and last years for which we had comparable lists of leading businesses when we began this project. We relate these indexes to long run growth at the end of this window, gauged by real per capita gross domestic product (GDP) growth, capital accumulation, and total factor productivity (TFP) growth from 1990 to 2000 . A ten-year window smoothes business cycle and transient crisis effects.

Economies with less persistently dominant large businesses grow faster than other 
countries with the same initial per capita GDP, level of education, and capital stock. ${ }^{1}$ This reflects faster productivity growth and capital accumulation, with the former more significant. For richer countries, the waning of large old private sector businesses drives the result. For poorer countries, the waning of one-time state own enterprises underlies our findings.

A low turnover of dominant businesses is related to high government spending, high regulatory barriers to entry, Civil Code legal systems, bank-centered financial systems, weak outside shareholder protection, and trade or capital barriers. These factors play a role in linking big business turnover to economy growth. Nonetheless, big business turnover unrelated to these factors still correlates with growth, especially in low-income countries.

Section 2 reviews the construction of our key variables and section 3 presents our key results. Section 4 considers possible political and economic explanations of the findings in section 3. Section 5 considers causality issues. Section 6 concludes.

\section{Data and Variables}

This section describes the raw data used to construct our big business stability indexes. It then explains the indexes themselves, the growth measures and the other variables central to our empirical tests.

\subsection{Big Business Sector Data}

Our data are hand-collected from the 1978 and 1998/99 editions of Dun \& Bradstreet's Principals of International Business. We use this source because it includes a wide spectrum of businesses: privately held companies, publicly held companies, cooperatives, and state controlled

\footnotetext{
${ }^{1}$ Note that the question of large firm stability is separate from that of optimal firm size. Acs et al. (1999) find that
} 
enterprises (S.C.E.s). ${ }^{2}$ This circumvents sample selection problems due to stock exchanges, and hence listed firms, being less important in some countries than others. Comparisons with annual reports show the 1978 volume to contain mainly 1975 figures, so we call this 1975 data. The 1998/99 volume generally contains 1996 figures, so we call it 1996 data.

Our final sample of 44 countries, listed in Table 1, meets the following criteria.

1. The country must appear in both the 1978 and 1998/99 editions of Principals of International Business. This eliminates transition economies.

2. We delete small economies whose tenth largest company has fewer than 500 employees and which have less than ten companies whose labor forces are listed in both editions. This removes microstate economies, which may differ fundamentally from larger countries.

3. We drop countries involved in major wars, including civil wars, between 1975 and 1996.

4. We require data on education and capital assets because these initial conditions are known to affect economy growth, and are needed as controls in our regressions.

5. We require comparable national income accounts data to construct comparable economic growth measures. This limits us to countries included in the Penn World Tables.

[Table 1 about here]

\subsection{Measuring the Stability of Leading Businesses}

We first need a list of each country's top businesses in each of 1975 and 1996. La Porta et al. (1999a), Claessens et al. (2000), Faccio and Lang (2002), and others show that large businesses

US industries containing larger firms show evidence of faster productivity growth. Rapid turnover of large firms need not imply a steady state characterized by a preponderance of small firms.

${ }^{2}$ We use the term state controlled enterprise (S.C.E.) rather than state owned enterprise (S.O.E.) because the state may hold a control block without owning the firm outright. 
in many countries, the US and UK being notable exceptions, are not single firms but business groups - constellations of listed corporations tied together by equity control blocks and usually all ultimately controlled by a single wealthy individual or family. We therefore define a country's largest businesses as its largest firms or business groups.

We start with the list of businesses in Dun \& Bradstreet, and conduct an extensive search to determine ultimate controlling shareholder of each firm. We then consolidate affiliated firms into corporate groups accordingly. To do this, we search Google, online databases such as Hoover's online, corporate websites, Worldscope, SDC, Forbes' annual lists of billionaires, newspaper archives, case studies, and academic research papers. We define a firm as controlled if it is so defined in any of these sources, or if $20 \%$ or more of its stock is voted by a firm, wealthy family, government, trust, or bank. ${ }^{3}$

We define a business's size as the number of people it employs. For business groups, this is the total number of employees in all the group's component firms. Employee tallies for business groups are cross-checked whenever possible across the various sources mentioned earlier. We measure firm size by employees because this lets us include both listed and private firms. The latter typically do not disclose their assets or sales, other common measures of firm size.

The consolidation of firms into business groups leaves some countries, like Sweden and South Africa, with a very few very large dominant businesses. Thus, even the $15^{\text {th }}$ or $20^{\text {th }}$ largest business in some countries is quite small. We therefore define each country's big business sector as its 10 largest businesses. If ties occur for the tenth business, all the ties are included.

\footnotetext{
${ }^{3}$ La Porta et al. (1999a) shows that $51 \%$ is not necessary as a single dominant shareholder can exert effective control when all other shareholders are small. We use voting rights to assign control, for cash flow rights and voting rights diverge substantially in some countries because of dual share classes and control pyramids.
} 
In smaller countries, or countries with business groups rather than freestanding firms, this is an exhaustive list of large businesses. In larger economies, it is a sampling of big businesses biased towards the biggest. For a very small economy, even the top ten list can still include what would be considered "small firms" in larger countries. This necessitates controlling for country size, or for the importance of the top ten firms relative to the economy, in subsequent analyses.

The next issue is what sorts of businesses to include. We exclude enterprises that are not normally included in countries' private sectors: educational services (SIC: 82), health services (SIC: 80), membership organizations (SIC: 86), noncommercial research organizations (SIC: 8733), and government agencies (SIC: 91-97). Beyond this, a degree of judgment is inevitable, for excluding any or all of three other categories of businesses might also be reasonable.

Financial sector businesses might be excluded. King and Levine (1993) show that capital market development positively affects growth. Including financial businesses in our top ten list might capture spuriously the impact of financial system development on growth. Business groups containing financial and non-financial firms are assigned to one category that accounts for the greater share of their employees.

Foreign owned enterprises might be excluded. Multinational subsidiaries are plausibly more affected by global conditions than by their host countries' economic conditions. However, some domestically based businesses might also have foreign operations, so this argument is not clear-cut. Countries that open up to the global economy gain multinational subsidiaries, and countries that isolate themselves lose multinational subsidiaries. Either could alter their top ten lists. Sachs and Warner (1995) and others show that openness contributes to economic growth and global convergence. Hence, including foreign owned enterprises might capture spuriously the impact of openness on growth. 
Any enterprise that was state controlled for any part of our window might be excluded. S.C.E.s economic motives might differ from those of purely 'for-profit' businesses. These motives might range from the efficient provision of public goods and promotion of new industries to wasteful government activism, bureaucratic entrenchment, and blatant corruption. These motives aggregate to an uncertain effect on growth; though Hayek (1944) and others argue eloquently that their net effect is negative. Regardless of the sign, including S.C.E.s might capture spuriously the impact of the size of the government on growth. Since import substitution and socialist ideologies induced extensive nationalizations in the 1970s and a resurgence of liberal ideology in the 1990s induced waves of privatizations, this problem may be especially severe during our time window.

To deal with these issues, we construct several alternative lists of top ten businesses in 1975, and again in 1996:

List I - Includes all businesses: financial and non-financial, domestically controlled and foreign controlled, as well as private sector and state controlled. Privatizations and nationalizations are taken as continuations of the same business, but S.C.E.s that fail, are taken over, or are broken up are classified as not surviving.

- List II - List I, but excluding businesses primarily the financial sector - banks, insurance companies, and investment banks. We define the financial sector as SIC codes $60-64$, as reported in Dunn and Bradstreet's Principals of International Business.

- List III - List II, but excluding foreign controlled enterprises. We infer foreign control if a foreign person votes at least a twenty percent stake and is the largest shareholder.

List IV - List II, but excluding S.C.E.s. We consider an enterprise to be state controlled if a government holds at least a twenty percent voting stake and is the largest shareholder. 
List V - The intersection of Lists III and IV; that is, list I excluding financial companies, S.C.E.s, and foreign controlled enterprises.

We wish to see if economic growth is related to the stability of a country's largest businesses. To quantify this, we must define which leading businesses from 1975 remain stable as leading businesses through 1996. One obvious approach is to define stable as "still in the top ten list in 1996". But a growing economy might let new businesses join the top ten, even though the 1975 top ten still prosper. A more nuanced definition of stability might spotlight 1975 top ten businesses that grew at least as fast as GDP, regardless of the 1996 top ten list. Other alternatives might define stability as a 1975 top ten business retaining at least $n$ percent of its 1975 labor force, where $n$ can be e.g. 50\%, 25\%, or 10\%. A combined definition might designate a top 1975 business as stable if it is either in the 1996 top ten list or it grew (or shrank) at some minimal rate from 1975 to 1996 . While each definition is arbitrary in some respect, robustness checks discussed below show that all yield similar empirical results.

In the tables, we use a combined definition - a leading 1975 business as stable if it remains in the top ten list in 1996 or grew at least as fast as its country's GDP from 1975 to 1996. That is, we define a country's employee-weighted stability index as

$$
\Omega_{L 75}^{G D P}=\frac{\sum_{i=1}^{10} \max \left[\delta_{i}, \eta_{i}\right] L_{i}}{\sum_{i=1}^{10} L_{i}}
$$

where $L_{i}$ is the 1975 labor force of 1975 top ten business $i$,

$$
\delta_{i}=\left\{\begin{array}{l}
1 \text { if } i \text { is in the top ten lists in both } 1975 \text { and } 1996 \\
0 \text { otherwise }
\end{array}\right.
$$

and 


$$
\eta_{i}=\left\{\begin{array}{l}
1 \text { if } i \text { grew at least as fast as GDP in the period } \\
0 \text { otherwise }
\end{array}\right.
$$

We construct one such index for each variant of each country's list of top ten businesses. We also construct a set of analogous equally weighted stability indexes denoted $\Omega_{E}^{G D P}$; defined

$$
\Omega_{E}^{G D P}=\frac{1}{10} \sum_{i=1}^{10} \max \left[\delta_{i}, \eta_{i}\right]
$$

To construct these indexes, we must assess the 1996 fate of each 1975 top ten business. This requires assembling a detailed history of each business.

Some businesses change names. For example, some Malaysian company names contain the abbreviation BHD in one Dun and Bradstreet volume, but Berhad (corporation in Malay) in the other. Likewise, Finland's Nokia is listed as OY NOKIA AB in one edition and NOKIA OYJ in the other. The choice of language sometimes causes confusion too. For example, the Japanese company listed in the 1975 data as Sumitomo Kinzoku Kogyo KK is listed under its English name, Sumitomo Metal Industries Limited, in 1996. These changes are easily traced.

Other name changes are less obvious, but are revealed in the detailed histories we construct for each business. We compile these from company websites, business history books, and biographies of the principals of our 1975 top ten businesses. Where this leaves ambiguities, we scan through newspaper records, and, in many cases, phone archivists at particular companies. These efforts, plus telephone inquiries to bankers, brokers, and finance professors in different countries, clarify the fates of all our 1975 top ten businesses.

The fates of a few businesses are intrinsically ambiguous. For example, some spin off divisions. Although the core business may be smaller in 1996, the aggregation of all successor businesses might be large. In general, we follow the principal successor business only. In some cases, this is problematic. For example, the Argentine state controlled enterprise Servicios 
Electricos del Gran Buenos Aires SA (Segba) is one of that country's top ten businesses for 1975. In the early 1990s, it split into Edenor and Edusur - with roughly equal numbers of employees going into each. In this case, we take the combined employees of the two successors in assigning continued importance to the predecessor business.

Table I reports the employee-weighted and equal-weighted stability indexes based on lists I and V for each of our 44 countries. Interpreting these indexes is straightforward. For example, the stability index of the United States based on list I, the minimally inclusive list which excludes financial, government controlled, and foreign controlled enterprises, is $\Omega_{L 75}^{G D P}=$ 0.531. This means that $53.1 \%$ of the employees of the top 10 businesses of 1975 worked for businesses that either remain in the top 10 list for 1996 or created jobs at least as fast as the growth rate of US GDP from 1975 through 1996. Similarly, Japan's equal-weighted stability index is $\Omega_{E}^{G D P}=0.7$, indicating that seven of Japan's top ten employers in 1975 either remain among it's top ten in 1996 or created jobs at least as fast as Japanese GDP grew. In general, the top businesses in higher income countries are more stable than those in developing economies.

Our employee-weighted and equal-weighted indexes are highly positively correlated, with $\rho=0.851(\pi<0.01)$ for the maximally inclusive indexes and $\rho=0.824(\pi<0.01)$ for the minimally inclusive indexes. The indexes based on minimally versus maximally inclusive lists are also highly significantly correlated with each other $(\pi<0.01$ in all cases), with point estimates in the 0.52 to 0.66 range. Indexes based on different lists are more highly correlated among higher income countries.

The upper panel of Table 2 presents univariate statistics for our stability indexes.

[Table 2 about here] 


\subsection{Measuring Economic Growth}

Ideally, we would measure economic growth subsequent to, and therefore potentially 'caused by' top business stability. However, Schumpeter $(1912,1942)$ and others stress that the economic effects we study operate only over the very long term - time clocked in generations rather than years. More frequent data would therefore not be helpful. Genuinely augmenting our data with more time periods would require going further back in time to the mid and early $20^{\text {th }}$ century. This is not possible given available data, so we are limited to a single cross section of data, in which we use our big business stability indexes, measured over 1975 to 1996, to explain long run growth at that window's endpoint.

Long run growth cannot be measured easily at a point in time, for annual growth rates are distorted by business cycles and even transient crises. We therefore gauge long term growth using observed growth over a window attached to 1996. Requiring that the window begin at 1996 would let us use past stability to predict future growth - an econometrically desirable temporal arrangement of variables. However, a short window beginning in 1996 generates noisy variables because its endpoints are contaminated by economic crises in East Asia and parts of Latin America. A longer window beginning in 1996 is not possible yet, for many countries publish national income accounts data with a lag of several years and these are rendered in comparable form in the Penn World Tables only after further delay. Moreover, a longer window beginning in 1996 would also induce noise, for big business stability changes in its early years might affect economic growth in its later years.

We therefore define long-term economic growth as per capita GDP growth

$$
\Delta \ln (y)=\ln \left(\text { per capita } G D P_{2000}\right)-\ln \left(\text { per capita } G D P_{1990}\right)
$$


from 1990 to 2000 - a ten year window roughly centered on the endpoint of the window over which we gauge big business sector stability. Data are from the Penn World Tables, Version 6.1, which include comparable national income accounts figures through $2000 .{ }^{4}$ GDP figures are in US dollars at purchasing power parity, and inflation-adjusted to 1996 dollars to remove differences in inflation rates and living costs across countries. Since $\Delta \ln (y) \cong \Delta y / y$, we interpret $\Delta \ln (y)$ as a fractional growth rate in per capita GDP.

The Penn World Tables let us decompose overall growth into growth due to capital accumulation and growth due to increased total factor productivity (TFP). To do this, we first measure each country's rate of per capita physical capital growth, $\Delta \ln (k)$, from 1990 to 2000. To estimate $\ln (k)$ at each endpoint, we assume an initial capital stock of zero for 1950 and construct a time series $K_{i, t}$ of total stock of physical capital in country $i$ in year $t$ recursively as

$$
K_{i, t+1}=K_{i, t}+I_{i, t}-\delta K_{i, t}
$$

where $I_{i, t}$ is aggregate real investment for country $i$ in year $t$, from Penn World Table 6.1, and $\delta$ is a depreciation rate of $7 \%$ under the perpetual inventory method. Scaling the total real physical capital stock by population yields per capita real physical capital stock. This procedure is similar to that in King and Levine (1994).

We then follow the methodology of Beck, Levine and Loayza (1999) to estimate each country's TFP growth as the growth in its per capita GDP minus 0.3 times the growth of its per capita physical capital. ${ }^{5}$

\footnotetext{
${ }^{4}$ The Penn World Tables are available from the National Bureau of Economic Research at www.nber.org.

${ }^{5}$ Caselli (2003) shows this decomposition of economy growth changes nontrivially if the capital share exceeds $1 / 3$. As robustness checks, we experimented with a range of capital share assumptions. Estimates based on Caselli's methodology and constant assumptions up to 0.4 generate results similar to those shown. We follow the popular approach of setting the capital share to 0.3 in the tables.
} 
The second panel of Table 2 presents summary statistics. The mean of 0.223 for $\Delta \ln (y)$ indicates that the typical country's per capita GDP rose by about $22.3 \%$ from 1990 to 2000 in real US dollars at purchasing power parity. Likewise, the average growth in real per capita physical capital stock is $26.3 \%$ and the average total factor productivity growth is $14.4 \%$. The ranges of these three measures are wide: from $-8.3 \%$ (Venezuela) to $62.4 \%$ (Israel) in total growth, from $-4.2 \%$ (Venezuela) to $46.7 \%$ (Israel) in total factor productivity growth, and from $21.7 \%$ (South Africa) to $67.4 \%$ (Korea) in real per capita physical capital accumulation. ${ }^{6}$

\section{Findings}

Our central finding is that a more stable list of large businesses is associated with slower growth. We first show this with simple correlations and then turn to regressions analogous to the basic models surveyed in Mankiw (1995), but adding stability as an additional independent variable. The section concludes with a robustness discussion.

\subsection{Simple Correlations}

Table 2 Panel B presents simple correlations between our growth measures and stability indices. All our maximally inclusive stability indexes are significantly negatively correlated with all three growth measures - with significance levels somewhat lower for equally weighted than employee-weighted stability indexes. The minimally inclusive indexes - which drop financial, foreign-controlled, and state-controlled businesses - tell a slightly different story. Total per capita GDP growth and TFP growth are negatively correlated with these stability indexes, but

\footnotetext{
${ }^{6}$ Another approach would look analogously at the turnover in each country's list of leading industries. We are pursuing this elsewhere. While this might seem a simpler line of attack, data problems actually make it considerably more complicated.
} 
capital accumulation is not significantly correlated with our minimally inclusive stability indexes- though the correlation point estimates remains negative.

\subsection{Regressions of Long-Term Economic Growth on Big Business Stability}

Economic growth rates are known to be higher for countries with lower initial levels of income, more educated workforces, and more extensive capital assets. ${ }^{7}$ Table 2 Panel B shows that our big business stability indexes correlate with these initial condition determinants of economic growth. Thus, the simple correlations described above might only reflect known determinants of economic growth.

We therefore follow Mankiw (1995) and regress our growth measures on a big business stability index controlling for initial income, initial stock of physical capital, and initial stock of human capital. Thus, we run regressions of the form

$$
\left[\begin{array}{c}
\text { economy } \\
\text { growth } \\
\text { rate }
\end{array}\right]=\beta_{0}+\beta_{1}\left[\begin{array}{c}
\text { initial } \\
\text { income } \\
\text { level }
\end{array}\right]+\beta_{2}\left[\begin{array}{c}
\text { initial } \\
\text { physical } \\
\text { capital }
\end{array}\right]+\beta_{3}\left[\begin{array}{c}
\text { initial } \\
\text { human } \\
\text { capital }
\end{array}\right]+\beta_{4}\left[\begin{array}{c}
\text { corporate } \\
\text { stability } \\
\text { index }
\end{array}\right]+\varepsilon
$$

where the economic growth rate is either per capita GDP growth, TFP growth, or capital accumulation and big business stability index is one of the stability indexes, all as defined above.

The control variables in (7) are as follows.

Initial income level is the logarithm of 1990 real PPP US dollar per capita GDP, $\ln (y)$, as in the Penn World Tables. Initial physical capital stock is the logarithm of real per capita physical capital in $1990, \ln (k)$, from (6) in Section 2. As a proxy for the initial human capital stock per capita, we take the logarithm of the average years of education for people aged 25 or over, $\ln (h)$, from Barro and Lee (2000). 
Thus, the regressions we run take the forms

$$
\text { growth }=\beta_{0}+\beta_{1} \ln (y)+\beta_{2} \ln (k)+\beta_{3} \ln (h)+\beta_{4} \Omega+\varepsilon
$$

where $\Omega$ is $\Omega_{L 75}^{G D P}$ or $\Omega_{E}^{G D P}$. Table 3 presents regression coefficients.

[Table 3 about here]

Panel A reports full details for regressions using minimally inclusive equal-weighted stability indexes. The indexes all attract significant negative coefficients in regressions explaining per capita GDP and TFP growth. That is, more stable dominant businesses are associated with slower economic growth and slower productivity growth. Our stability indexes can be interpreted as inverse measures of the marginalization of previously dominant businesses. This interpretation of our result implies that a greater marginalization of past leading businesses is significantly associated with faster growth, faster productivity growth, and even faster capital accumulation.

Panel B reports regression results using stability indexes based on each variant of our top ten lists described above. For brevity, the table reports only the regression coefficients on those indexes. In every case, big business stability is negatively and significantly related with both per capita GDP growth and TFP growth. While the stability measures also attract negative coefficients in every regressions explaining capital accumulation, these are significant only in four of the ten stability variants; and three of these are for indexes constructed from top 10 lists including sometime SCEs.

\footnotetext{
${ }^{7}$ See Barro (1991), Mankiw (1995), and others. Barro uses initial capital investment, rather than assets. Our results are robust to using either.
} 
These relationships are economically as well as statistically significant. To save space, and to be conservative, we discuss only the results for indexes based on the minimally inclusive top ten lists, which also have the least significant results. A one standard deviation increase in the labor-weighted stability index is associated with a per capita GDP growth drop of $0.22 \mathrm{x}$ 0.227 or $5 \%$. This is approximately $36.5 \%$ of the cross-country standard deviation in real per capita GDP growth. Similarly, a one standard deviation increase in the equal-weighted stability index is associated with a per capita GDP growth depressed by $47.5 \%$ of the standard deviation of that variable. A one standard deviation increases in these same labor or equal-weighted indexes is likewise associated with total factor productivity growth reductions of $32.9 \%$ or $44.8 \%$, respectively, of the standard deviation of that variable. Also, a one standard deviation increase in these indexes is associated with per capita capital accumulation lower by $27.4 \%$ and $32 \%$, respectively, of its standard deviation.

In summary, big business sector stability accounts for a substantial part of the variation in economic growth across countries. The regressions tie more marginalization of old top ten businesses to faster growth.

\subsection{Rich or Poor?}

Interestingly, including S.C.E.s in the list of dominant businesses relates the stability indexes (Lists II and III) to slower capital accumulation (Panel B of Table 3). S.C.E.s are more pervasive in the top ten lists of lower income economies, whose capital markets are typically ill developed. S.C.E.s might affect growth either by helping bridge this gap or by widening it as they crowd out private investment or otherwise impede financial development. More generally, Gerschenkron (1962) and others argue that economic growth in rich countries differs qualitatively from that in 
poor countries "catching up." Therefore, we examine the relationship between growth and big business sector stability in subsamples of initially rich and poor countries. ${ }^{8}$

[Table 4 about here]

Table 4 reproduces the regressions of Table 3 for rich and poor country subsamples. We define countries as rich if their per capita GDP in 1990 is above the median for the 44 countries in our sample.

Among richer countries, slower per capita GDP and total factor productivity growth are associated with significantly higher minimally inclusive stability indexes, which include only non-financial private sector domestically controlled businesses. Capital accumulation is statistically unrelated to any indexes in rich countries. Including foreign controlled enterprises generates quite similar results, with slightly less statistical significance; and including S.C.E.s renders all the indexes entirely insignificant - though negative signs emerge in almost every case. Thus, for developed countries, the marginalization of top non-financial domestically controlled private sector businesses is most significantly associated with faster growth.

Among poorer countries, significant results obtain only if S.C.E.s are included in tallying the stability of large businesses. For these countries, labor-weighted stability indexes are associated with slower real per capita GDP growth, total factor productivity growth, and capital accumulation. These results link the stability of large S.C.E.s in poorer countries to the results in Table 3B based on versions I, II, and III of the top ten lists. They also suggest that, in developing countries, the turnover of dominant private sector businesses is not significantly related to growth, though again, all point estimates are negative.

\footnotetext{
${ }^{8}$ Aghion et al. (2004) develop a comprehensive formal model based on Gerschenkron's insight. Our results in this section broadly support their model's validity.
} 


\subsection{Robustness Tests}

These basic results in Tables 3 and 4 survive a battery of robustness checks. Sensible changes in regression specifications and variable definitions generate qualitatively similar results. By this we mean that these changes do not alter the sign, approximate magnitude, or significance of the coefficient on the big business stability indexes.

Residual diagnostics analyses show that our results are not affected by outliers. For example, Cook's D and DFFITS tests indicate no outliers. Student residuals point only to Ireland as a potential outlier. However, dropping that country from our sample produces qualitatively identical results. Generalized White tests reject heteroskedasticity.

We wish to insure that differences in country size do not affect our results. The top ten businesses in a small economy might be smaller in absolute size than those in a large economy; and yet might constitute a larger part of the overall corporate sector. We control for this by including country size as a control. To gauge country size, we use the logarithm total 1990 GDP, adjusted to 1996 dollars at purchasing power parity exchange rates, which we denote $\ln (Y)$, from Penn World Table 6.1, and run

$$
\text { growth }=\beta_{0}+\beta_{1} \ln (y)+\beta_{2} \ln (k)+\beta_{3} \ln (h)+\beta_{4} \ln (Y)+\beta_{5} \Omega+\varepsilon
$$

The country size variable is uniformly statistically insignificant, and its inclusion does not qualitatively change our results. Similarly, using the log of total population, or area in square kilometers, to control for country size does not change our results. ${ }^{9}$

The top ten businesses in some countries, such as Sweden and South Africa, are essentially the population of large businesses. In others, like the United States and United

\footnotetext{
${ }^{9}$ One alternative approach is to make the length of our lists of large businesses proportional to the size of the economy by including more firms in larger economies. However, this is operationally difficult because gleaning accurate corporate histories in remote countries is often quite involved. Moreover, the choice of the proportionality factor also introduces a new degree of arbitrariness. We leave this to possible future research.
} 
Kingdom, the top ten are merely the largest from a broad range of big businesses. Countries with only a few truly huge businesses might be qualitatively different from those with many roughly equally large businesses. To control for this, we include the labor force of the top ten businesses as a fraction of national population (or GDP) in 1975 as an additional control. This also generates qualitatively similar results to those shown.

Our results might also depend on the industrial structures of economies. Specifically, dependence on natural resources might affect big business sector stability and economic growth. Resource abundant countries may have large natural resources businesses that remain large to exploit economies of scale. Yet, for a variety of political and institutional reasons, these countries might also remain poor (Rodriguez and Sachs, 1999 and Sachs and Warner, 2001). However, including the resource dependence measure of Hall and Jones (1999) as an additional control variable preserves the rough magnitudes and significance levels of the stability measures. $^{10}$

Other versions of the stability indexes behave similarly to those shown in the tables. Defining stability as a 1975 top ten business remaining in the 1996 top ten list; retaining 50\%, or $25 \%$, or $10 \%$ of its 1975 employment in 1996; or a disjunction of the former with any of the later criteria all generate qualitatively similar results to those described above. The reported indexes capture one measure of the extent to which 1975 top businesses remain important; the alternative

\footnotetext{
${ }^{10}$ The mining variable in Hall and Jones (1999) is for 1988 "when possible or the closest available year." We follow their procedure to construct an analogous variable using 1975 and 1996 data from the World Development Indicators database. We construct two sets of control for natural resource dependence using fuel, oil, and metals exports over merchandise exports (FOM). The first set includes two variables - the level of FOM in 1975 and its change from 1975 to 1996. The second set is the average of FOM in 1975 and 1996. Including either set of resource dependence controls in our regressions preserves the magnitudes and significance levels of the stability variables in per capita GDP and TFP growth regressions.
} 
indexes capture the extent to which they remain dominant, or merely escape from being marginalized. ${ }^{11}$

One alternative stability index we constructed does generate qualitatively different results. We developed a continuity of control index, which looks at the family name of each company's top executive in 1975 and 1996. Our idea was to capture the fraction of the big business sector that remained under the control of the same individuals or families over the two decades. Labor-weighted and equal weighted indexes of continuity of control are uncorrelated with GDP growth, productivity growth, and capital accumulation. One interpretation is that creative destruction requires more than a turnover of top management. A turnover of big businesses, and perhaps in their intangible corporate routines as well as physical assets, is needed. Another is that our continuity of control index is too noisy to be of use because different last names may correspond to continuity if CEOs are replaced by nephews, acolytes, and the like; and that the same last name may correspond to discontinuity if a son's policies differ greatly from his father's. Further research is needed to clarify these issues.

In a further set of robustness tests, we substitute two alternative productivity growth measures for those used in the tables. Proposed by Mankiw (1995) and Hall and Jones (1999), respectively, these include human capital as a factor of production. These alternatives do not change the significance of the stability indexes.

Next, replacing real GDP per capita growth with per capita GNI (gross national income) also produces patterns of signs, coefficient size, and statistical significance very similar to those shown in the Tables. GNI can be measured in two ways. The first uses the Atlas Method and

\footnotetext{
${ }^{11}$ Since results based on these other versions of the continued importance indexes are similar to those in the tables, we do not report them to conserve space. These results are available from the authors upon request.
} 
converts national currency to current US dollars, and the second converts national dollars to "international dollars" at purchasing power parity. Both measures produce similar results.

Finally, if we measure initial stock of human capital by the logarithm of the average number of years of total education in the male population over 25 in 1990, rather than the general adult population (on the grounds that males are more likely to be in the work force in many countries), we again obtain qualitatively similar results.

\section{Institutional Underpinnings}

The previous section shows that greater private sector bug business stability is associated with slower economic growth, slower total factor productivity growth, and, albeit less significantly, less capital accumulation. This is consistent with creative destruction underlying economic growth. It also begs the question of why big businesses are more stable in some countries than others. Although many factors doubtless matter, we focus on differences in economic institutions, for these have also been related to long term growth. Our finding that, for developing countries, our result is evident only if S.C.E.s are included in tallying big business stability raises the possibility that the State may play a role in these differences. Other institutional arguments we consider turn on financial development and economic openness.

To explore these institutional arguments, we test for relationships between proxies for institutional effects and our stability indexes, $\Omega$. These tests are regressions of the form

$$
\Omega=c_{0}+c_{1} \ln \left(y_{0}\right)+c_{2} \ln (k)_{0}+c_{3} \ln \left(h_{0}\right)+c_{4} \Phi+u
$$

where the initial income, physical capital, and human capital controls are as in (8) but for 1975. These regressions use equal and labor weighted stability indexes constructed using all five sets of top ten lists. The institutional development variable, $\Phi$, is a measure of the economic role of the 
government, the development of the financial system, or the country's openness to the global economy. We now turn to the specific institutional variables in turn.

\subsection{Government}

The size of the government sector might plausibly underlie the observed relationship between big business stability in a range of related ways. These depend on the benevolence or malevolence of the political elite.

A highly benevolent government might seek employment stability and/or an egalitarian income distribution. If the government views the country's large businesses as important providers of steady middle-income jobs that promote these ends, it might intervene to stabilize its big business sector. ${ }^{12}$ A benign government might view general economic stability as a public good per se. ${ }^{13}$ Big businesses can also be handy channels through which politicians can affect social and political policies, as in Högfeldt (2004), and politicians - benevolent or self interested - might protect such businesses to preserve their power. ${ }^{14}$ For these or other reasons, benevolent politicians might act to preserve established large businesses even if this retards growth.

\footnotetext{
${ }^{12}$ For example, when the German government bailed out Philipp Holzmann, Finance Minister Hans Eichel declared that "the government has a responsibility to step in if a major German company is about to collapse and cost thousands of people their jobs." (See Edmund Andrews 'Navigating the Economy of a Changing Germany', New York Times, December 7, 1999.) The same motive seems to underlie Chancellor Gerhard Schroeder's pressure on German banks to save the jobs of the 22,000 employees of the bankrupt engineering firm Babcock Borsig AG with a $\$ 700$ to $\$ 800$ million bailout. (See 'Schroeder Seeks bailout Aid for Bankrupt Firm' International Herald Tribune, July 6, 2002, p 11.)

${ }^{13}$ Such beliefs seem to have led the Japanese government to propose a $¥ 200$ billion ( $\$ 1.90$ billion) bailout of Sogo Department Stores, which Asiaweek described as part of Japan's long tradition of corporate bailouts designed to minimize "confusion". See Jonathan Sprague and Murakami Mutsuko 'Tokyo's Sogo Shocker - A bailout and a reversal show no policy at all' Asiaweek, 26(29), July 28, 2000. Note, however, that Asiaweek continues that, to the bewilderment of senior politicians, the bailout was derailed when "[t]he public exploded over the use of their tax money to rescue a poorly managed private company."

${ }^{14}$ For example, Business Week reports Malaysian Prime Minister Mahathir unapologetic about his government's policy of selecting a handful of wealthy businessmen for privileges and assigning them the role of creating jobs, implementing big projects, and keeping the economy growing. The article quotes Mustapha Mohamed of the Finance Ministry saying "We view Malaysia as a corporation, and the shareholders in the government are companies." and "To the extent you help the bigger guys, the smaller guys benefit." See Sheri Prasso, Mark Clifford
} 
Regardless of which reason is paramount, state intervention to stabilize big business can hinder growth in a variety of ways. Government crowds out private investment, as in neoKeynesian macroeconomics. Government intervention adds political risk to normal business risks, deterring investment. Red tape, delays, and other political fixed costs block entry by new competitors, as in Djankov et al. (2002), Krueger (1974), and Olson (1963, 1982). All three link slow growth to high stability.

Alternatively, a country's government might be controlled to some extent by its great businesses, and manipulated to their benefit - see Hayek (1960). Stigler (1971) argues that large businesses capture the bureaucrats who regulate them, and Beason and Weinstein (1996), among others, present evidence of this. Tullock (1967) argues more generally that returns to political rent-seeking rise with the extent of state interventionism. ${ }^{15}$ Krueger (1993), Murphy et al. (1991, 1993), and others argue that, if governments make rent-seeking more lucrative, businesses divert resources to rent seeking and away from real investment, slowing growth. ${ }^{16}$ This line of reasoning is consistent with our earlier finding that the stability indexes that include S.C.E.s best explain slow growth in low income countries. ${ }^{17}$

We gauge the sheer importance of government in the economies of each country with 1975 public sector consumption over GDP, as reported in World Development Indicators. As a more nuanced measures of the role of the government in the economy, we also use the 1975 GINI coefficients from Deininger and Squire (1996) and the World Income Inequality database to measure income inequality, which benevolent government intervention arguable reduces. We

and Joyce Barnathan 'Malaysia: The Feud - How Mahathir and Anwar became embroiled in a clash that threatens to send Malaysia into upheaval' Business Week, October 28, 1998.

${ }^{15}$ Morck and Yeung (2004) argue that large, established, family controlled corporate groups are especially able rentseekers.

${ }^{16}$ Though Haber et al. (2003) argue that government capture by the business elite may be an optimal second best outcome absent the rule of law. 
also use a legal origin indicator variable, set to one for Common Law legal systems and to zero otherwise; and a measure of red tape barriers to entry. The legal origin indicator is from La Porta et al. (1997b), who link Common Law legal origins to better government institutions, especially to an independent judiciary and reduced official corruption. The red tape barrier measure is the logarithm of the "time required to obtain legal status for new business" in days, from Djankov (2002, Table 3). Unfortunately, the last variable is measured as of 1999, and so might be a result of faster growth or big business instability, rather than a cause. We examine it because entry barriers are clearly relevant to our stability measures, but concede that interpreting its coefficients is problematic.

[Table 5 about here]

Panel A of Table 5 shows that higher government consumption is significantly correlated with greater labor-weighted stability indexes; but only if they are based on lists IV and V, which exclude financial companies and sometime SCEs. This is consistent with big government favoring the continued economic importance of established big businesses. Greater stability is usually negatively, but insignificantly, related to income equality - undermining the idea that big business stability might promote egalitarian goals. Civil Code legal systems and longer delays in establishing new businesses legally are also associated with more big business stability, but only using indexes based on Lists I, II, or III, which include S.C.E.s.

Other tests we perform searching for links between stability and laudable social outcomes are uniformly insignificant. GINI coefficients in 1996 are uncorrelated with stability, as are

\footnotetext{
${ }^{17}$ Fisman and Svennson (2000), Fisman (2001), Fisman and Di Tella (2001), Johnson and Mitton (2003), and others document the first-order importance of political rent-seeking in low-income economies.
} 
changes in GINI coefficients from 1975 to 1996. Other equality or social policy outcome measures - unemployment, the variance of the unemployment rate, and indicator variables for various sorts of crises - are also unrelated to our stability indexes. The only exception is hardly breathtaking: 'government crises' are less frequent in rich countries with contemporaneously more stable large corporate sectors. If governments stabilize their large corporate sectors to promote such social goals, these interventions seem of limited success.

Big business stability is thus associated with Civil Law Legal systems and with worse red tape if we include S.C.E.s in our top ten lists. Otherwise, only the sheer size of government is related to larger stability indexes.

\subsection{Finance}

Schumpeter (1912) argues that a well-functioning financial system is a prerequisite for rapid economic growth because it allows innovative entrepreneurs to obtain financing. Outside investors' current legal rights vis à vis corporate insiders are indeed highly positively correlated with a country's financial development. ${ }^{18}$ King and Levine (1993) find that countries with better developed financial systems do grow faster. ${ }^{19}$ Schumpeter (1912) also holds that creative entrepreneurs' rapidly growing new businesses overwhelm old established businesses - a process he dubs creative destruction. Thus, better functioning financial systems and stronger investor legal rights might be associated with faster creative destruction, and hence with both faster

\footnotetext{
18 See La Porta et al. (1997a, 1997b, 1998, 1999b, 2000), Levine et al. (2003), and others. Rosenthal and Lamoreaux (2004a, 2004b), Aganin and Volpin (2004) and others argue that this cross-country relationship is a recent phenomenon. For overviews, see Glaeser and Goldin (2004) and Morck and Steier (2004).

${ }^{19}$ See also Bekaert and Harvey (1998), Khanna and Palepu (2000), La Porta et al. (2000), Levine (2002), Rajan and Zingales (2003), Johnson and Mitton (2003), Morck et al. (2000), Olsen (2000) and others.
} 
growth and a less stable big business sector. ${ }^{20}$

Digging deeper, Rajan and Zingales (2003) ask why, given this, so many countries have ill-protected investors and ill-developed financial markets. Perhaps historical and cultural factors intervene. $^{21}$ Or, the insiders of established big businesses might wield their political influence to weaken their countries' financial sectors. ${ }^{22}$ This erects a barrier to entry against upstart rivals and blocks creative destruction, stabilizing the big business sector but retarding growth.

We gauge financial development by the sheer size of the financial system and by the strength of investor protection. Financial system size is measured by 1975 credit to the private sector and by 1978 stock market capitalization, both as fractions of GDP, from Beck et al. (1999) and the World Development Indicators database. We gauge investor protection with the creditor and shareholder rights tallies assembled by La Porta et al. (1998). ${ }^{23}$

Panel B of Table 5 show that a large banking system (private sector credit is large relative to GDP) is associated with greater equally weighted stability indexes, except those based only on non-financial private sector businesses. In contrast, stock market size is unrelated to stability. Yet creditor rights appear unimportant, while shareholder rights are associated with reduced

\footnotetext{
${ }^{20}$ A related issue, raised by Rajan (1992) and others, is whether bank or stock market development matters more. Beck and Levine (2002) and Levine (2002) present evidence suggesting this is a second order issue. But see also e.g. Maurer and Haber (2004).

${ }^{21}$ La Porta et al. (1997a, 1997b, 1998), Stulz and Williams (2003), and others.

${ }^{22}$ See Morck, Stangeland, Yeung (2000), Pagano and Volpin (2001), Rajan and Zingales (2003), Perotti and Volpin (2004), Morck, Wolfenzon, and Yeung (2005), and others.

${ }^{24} \mathrm{La}$ Porta et al. (1998) index creditor rights from zero to four, assigning one point each when: (1) the country imposes restrictions, such as creditors' consent or minimum dividends to file for reorganization; (2) secured creditors are able to gain possession of their security once the reorganization petition has been approved (no automatic stay); (3) secured creditors have first priority on distribution of proceeds from asset sales of a bankrupted firm; and (4) management does not have to stay pending the resolution of a reorganization. Their shareholder right index ranges from zero to six, assigning one point each when: (1) proxy vote by mail is allowed; (2) shareholders are not required to deposit their shares prior to the General Shareholders' Meeting; (3) cumulative voting or proportional representation of minorities in the board of directors is allowed; (4) an oppressed minority mechanism exists (meaning that minorities shareholders have legal mechanisms against perceived oppression by directors); (5) the minimum percentage of share capital that entitles a shareholder to call for an Extraordinary Shareholders' Meeting is less than or equal to 10 percent, and (6) shareholders have preemptive rights that can only be waved by a shareholders' vote.
} 
stability indexes based on any lists that include S.C.E.s.

That a large banking system is associated with a more stable big business sector is consistent with other work. For example, Morck and Nakamura (1999) and Morck et al. (2000) argue that Japanese banks use their corporate governance influence to induce stability in that country's large businesses, rather than growth and dynamism, because their primary concern is the timely repayment of loans, not firm value maximization. Likewise, Perotti and von Thadden (2003) argue that democracies whose median voter values stability more, as a way of protecting her human capital, are biased towards bank as opposed to stock market development, precisely because banks act in this way.

Our shareholder rights measures are for the 1990s, rather than for 1975, and thus might measure effects, rather than causes of big business stability. For example, countries with large state controlled sectors in 1975 might have enacted shareholder rights so that privatizations would fetch more for their treasuries. However, La Porta et al. (1997a, 1997b) argue that shareholder rights are intrinsically stronger under Common Law legal systems, which were all in place long before 1975. The finding in Panel A that Common Law systems are associated with reduced stability when S.C.E.s are included in compiling those indexes suggests that S.C.E.s are less durable in Common Law countries. One possibility is that governments in these countries are more prone to privatize S.C.E.s when their social purposes cease, and these businesses are then taken over, merged, or fail. In Civil Code countries, with weaker shareholder rights, governments may find privatization less remunerative, and so hold on to their S.C.E.s.

\subsection{Openness}

Trade openness encourages businesses to specialize according to their countries' comparative 
advantages, while capital account openness lets domestic businesses access capital from abroad. Standard trade and investment theories imply that either form of openness should enhance growth. For example, Bekaert, Harvey and Lundblad (2005) show that capital account liberalization increases subsequent real economic growth by about $1 \%$ per year on average. From 1975 through 1996, most economies grew more open, and this appears to have induced more rapid growth. ${ }^{24}$ Lower stability indexes might thus reflect increasing openness forcing corporate sector adjustments to changing comparative advantage, capital costs, and competitive pressures.

Politicians might wield protectionism as a tool to protect established big businesses from more efficient foreign competitors. ${ }^{25}$ Or, protectionism might be adopted for purely ideological reasons, and the ensuing big business stability might be an unintended consequence. Rajan and Zingales (2003) argue that the principals of large established businesses were less successful at restricting entry by hobbling financial systems in more open countries. This might be because politicians' ability to serve special interests is more restricted in more open economies. ${ }^{26}$ If openness correlates with reduced rent seeking and easier entry by new businesses, it should also correlate with higher growth and lower stability indexes.

We capture trade openness with exports plus imports over GDP and capital account openness with foreign direct investment inflow over GDP. Panel C of Table 5 shows less trade and capital account openness corresponding to greater stability of leading private sector businesses (lists IV and V). ${ }^{27}$

\footnotetext{
${ }^{24}$ See Sachs and Warner (1995), Henry (2000a, 2000b, 2003), Bekaert et al. (2005, 2006), and others. But see also Edison et al. (2002).

${ }^{25}$ See Krueger (1993), Morck et al. (2000), Johnson and Mitton (2003), Rajan and Zingales (2003), and others.

${ }^{26}$ Ibid.

${ }^{27}$ Nevertheless, the result on trade openness is weak. Our trade openness variable is for 1975 . The impact of openness on stability could stem from both the level of openness and the increase in openness. The former is positively related to 1975 trade openness while the latter could behave in the opposite manner. Hence, the two forces could offset each other. We included change in trade openness from 1975 to 1996 as a right hand side
} 


\subsection{Rich and Poor Countries}

The pattern in Panel A of Table 5 is almost entirely due to high income countries. In addition, red tape costs and delays are associated with greater stability in high income countries even using indexes based on lists IV and V (no financial companies or S.C.E.s). Restricting the regressions in Panel A to low income countries yields few significant coefficients, but consistently negative signs on government size - big governments are (insignificantly) associated with less stable big business sectors. Red tape is associated (again insignificantly) with more instability if the indexes include only private sector businesses. If the top ten lists include a broader range of enterprises, no clear pattern of signs remains. Greater 1975 inequality is significantly associated with lower subsequent big business stability, but only if the index includes S.C.E.s.

The positive relationship between the banking system's size and stability is also due to high income countries, and is absent for low income countries. The link between greater shareholder rights and big business turnover (for lists including S.C.E.s) is significant in high and low income countries alike. The analogous relationship with Common Law legal origin is significant only in high income countries. One interpretation of this is that Common Law legal systems countries with extensive state-controlled sectors boosted shareholder rights so privatized S.C.E.s would fetch higher prices when sold to public shareholders.

In contrast, the greater private sector big business instability in more open countries, revealed in Panel $\mathrm{C}$, is due almost entirely to low income countries. Trade and capital account openness are uncorrelated with our indexes in high income countries, but the patterns evident in

variable, overlooking endogeneity. We still found little significance for both the change and the initial level of trade openness. 
panel C remain statistically significant across low income countries. Protectionism appears more important to big business stability in low income countries.

\subsection{Further Robustness Checks}

Residual diagnostics tests show that our results are not driven by outliers, and heteroskedasticity problems are rejected in generalized White tests.

If we substitute other variables likely to capture the same effects as those used, we obtain similar results. For example, using government spending instead of government consumption, or the "cost of obtaining legal status for a new business" as fraction of per capita GDP instead of the "number of days of delay" all yield results qualitatively similar to those shown in Panel A of Table 5shown . Using "total domestic credit", rather than "total credit to the private sector", over GDP likewise yields similar results to those shown in Panel B. Using the modified index of trade openness recommended by Frankel (2000) generates results similar to those in Panel $\mathrm{C}^{28}$.

\section{Big Business Stability Per Se?}

Any causal interpretation of the robust negative relationship between stability and growth in Section 3 must remain a hypothesis. We can devise no convincing way to rule out endogeneity based on reverse causality or latent variables. We must therefore consider implications of these alternative interpretations of our findings to assess their plausibility.

Reverse causality might induce the observed relationships if faster growth creates more and larger new businesses. However, why rapid growth need do this, rather than increase the

\footnotetext{
${ }^{28}$ Frankel (2000) points out that smaller countries are naturally more dependent on trade than larger ones, and so recommends "imports over GDP minus all foreign countries' GDP over world GDP." Intuitively, in a world without border, imports over GDP should equal foreign production over world production. If imports are higher than this, the economy is more open.
} 
size of old, dominant businesses, still requires an economic explanation. Indeed, our robustness checks link economy growth to more stringent definitions of 'continued importance' - like the business retaining at least $10 \%$ of its 1975 labor force in 1996. Economy growth appears correlated with absolute declines in the importance of old dominant businesses, not just their eclipse by rising stars. Rapid growth 'causing' the absolute decline of old dominant businesses thus seems a problematic reverse causality argument. In our view, Occam's razor decidedly favors creative destruction 'causing' growth and undermining old dominant businesses in the process.

Standard statistical procedures for assessing the direction of causality are difficult to apply in this situation. Granger causality tests require long time series. Since, Schumpeter $(1912,1939,1942)$ describes growth in the "very long run", with time measured in generations, not years, assessing economic growth and big business stability over higher frequency intervals is not useful. Adding a meaningful time dimension requires constructing stability indexes at appropriately long intervals into the deeper past. This is difficult because compiling the indexes we have took the better part of two years. Extending the data into the more remote past is beyond the scope of this study.

Latent variables are harder to dispose of than simple reverse causality. Intrusive government, sclerotic financial systems, and protectionism are all thought to retard growth. Perhaps these economy characteristics also stabilize established large businesses, inducing the patterns in our tables. The most direct way to deal with the latent variable problem is to run multiple regressions of growth on stability plus key institutional environment variables from Table 5, viz.

$$
\text { growth }=\gamma_{0}+\lambda_{1} \ln (y)+\gamma_{2} \ln (k)+\gamma_{3} \ln (h)+\gamma_{4} \Omega+\gamma_{5} \Phi+\varsigma
$$


where $\Omega$ is either $\Omega_{L 75}^{G D P}$ or $\Omega_{E}^{G D P}$ and $\Phi$ is a vector of the representative institutional variables shown to be significant in Table 5 - government as a fraction of GDP, a Common Law dummy, red tape, banking system size, and trade openness. Limited degrees of freedom preclude using the whole list of Table 5 variables, but the institutional variables are highly correlated so a representative measure for each economic effect suffices.

[Table 6 about here]

To conserve space, Table 6 reports only results for stability indexes based on maximally and minimally inclusive top ten lists. Even after including government size, a Common Law legal system indicator, the red tape measure, banking system development, and trade openness; stability retains its significant negative relationship with GDP growth and productive growth. Its negative relationship with capital accumulation remains significant only in regressions using equally weighted stability based on List V. Stability indexes based on List II, III and IV (not shown) yield almost identical results if GDP and productivity growth are the dependent variables. In regressions explaining capital accumulation, stability retains a significant negative coefficient only if it is defined using top-ten List II (value-weighted) or List III (both value and equal weighted).

These results are robust. Student residual statistics again identify Ireland as an outlier in the TFP growth regressions, but dropping it does not change the pattern of signs and significance. White general tests reject heteroskedasticity.

Repeating the regressions for the low and the high income sub-samples is problematic due to limited degrees of freedom. However, including institutional variables one-by-one 
provides some insight. In high income countries, the institutional variables eliminate the statistical significance of big business stability in explaining the growth measures. But in low income countries, the institutional variables leave big business stability significantly depressing per capita GDP growth, productivity growth and capital accumulation, as before, if sometime SCEs are included in the top ten lists. The institutional variables are generally insignificant. ${ }^{29}$

Table 6 thus reveals that stability per se has a negative relationship with growth, even in the presence of institutional control variables. This independent effect is more pronounced across low income countries. Indeed, across high income countries, institutional factors - small government, financial development, and openness - may well explain the link we detect between big business stability and slow growth. This thus indicates that, in high income countries, institutional factors explain economic growth, in part at least, because they determine the pace of creative destruction an economy can sustain.

\section{Conclusions}

Countries whose rosters of big businesses change less from 1975 through 1996 exhibit slower economic growth and total factor productivity growth in the 1990s. This effect is most evident in higher income countries, where stable lists of leading businesses also correlate with reduced capital accumulation in the 1990s. This effect is not due to new behemoths arising to push aside still thriving giants of 1975. Rather, it largely reflects old giants waning as new ones wax large.

A list of big businesses that changes less from 1975 to 1996 is associated with a larger government sector in 1975, a non-Common law legal origin, and higher barriers to entry against new competitors. A more stable big business sector is also associated with a larger banking

\footnotetext{
${ }^{29}$ These results are available from the authors upon request.
} 
system and weaker legal protection for outside shareholders. Openness to the global economy in 1975 correlates with reduced big business stability. Thus, the effect of big business stability on growth seems to work through these institutional factors, especially in high income countries. In low income countries, institutional factors do not capture the effects of big business stability on growth.

These results support Schumpeter's (1912) thesis that sustained long run growth requires a process of creative destruction, in which new corporate giants continually rise up to overthrow old leviathans, especially for developed countries. For developing countries, continuous direct involvement of government in big business seems a prime suspect for slowing growth. These results validate efforts to formalize and extend Schumpeter (1912), such as Aghion and Howit (1997). While we cannot speak to other time periods or specific industry or country settings, growth due to innovation by large established businesses, as in Schumpeter (1942), appears less generally important in recent decades.

Our findings raise the concern that big business in some countries might be excessively stable, and that this might retard economic growth. We recognize that further work is needed to clarify the direction of causation in the economics underlying these results. We welcome alternative interpretations of our findings and additional theoretical or empirical work that might cast light upon these issues.

\section{References}

Acs, Zoltan, Randall Morck, and Bernard Yeung, 1999. Productivity Growth and Firm Size Distribution. In Enterpreneurship, Small and Medium Enterprises and the Macroeconomy, Zoltan Acs, Bo Carlsson and Charlie Karlsson, eds. Cambridge University Press. 
Aganin, Alexander and Paolo Volpin. 2004. The History of Corporate Ownership in Italy. London Business School working paper.

Aghion, Philippe and Peter W. Howitt. 1992. A Model of Growth Through Creative Destruction. Econometrica 60 323-51.

Aghion, Philippe and Peter W. Howitt. 1998. Endogenous Growth Theory. MIT Press.

Aghion, Philippe, George-Marios Angeletos, Abhijit Banerjee and Kalina Manova. 2004. Volatility and Growth: Financial Development and the Cyclical Composition of Investment. Harvard Economics Department working paper.

Barro, Robert, 1991. Economic Growth in a Cross Section of Countries. Quarterly Journal of Economics 106(2): 407-43.

Barro, Robert, and Jong-Wha Lee, 2000. International Data on Educational Attainment: Updates and Implications. Manuscript, Harvard University.

Beason, Richard, and David Weinstein, 1996, Growth, Economies of Scale, and Targeting in Japan (1955-1990), Review of Economics and Statistics 78 (2): 286 - 95.

Beck, Thorsten and Ross Levine. 2002. Industry growth and capital allocation: Does having a market- or bank-based system matter? Journal of Financial Economics 64(2) 147.

Beck, Thorsten, Ross Levine, and Norman Loayza, 1999. Finance and the Sources of Growth. World Bank Working Paper.

Bekaert, Geert, and Campbell Harvey, 1998. Capital Markets: An Engine for Economic Growth. Brown Journal of World Affairs 5(1): 33-53.

Bekaert, Geert, Campbell Harvey, and Christian Lundblad, 2005. Does Financial Liberalization Spur Growth? Journal of Financial Economics 77(1) 3-56.. 
Bekaert, Geert, Campbell Harvey, Chris Lundblad, and Stephan Siegel, 2006. Growth Opportunities and Market Integration, Journal of Finance, forthcoming.

Caselli, Francesco, 2003. The Missing Input: Accounting for Cross-Country Income Differences, in Philippe Aghion and Steven Durlauf, ed(s), Handbook of Economic Growth.

Caves, Richard. 1982. Multinational Enterprise and Economic Analysis. Cambridge Univ. Press. Claessens, Stijn, Simeon Djankov, and Larry H.P. Lang. 2000. The Separation of Ownership and Control in East Asian Corporations, Journal of Financial Economics 58 (1-2): 81-112.

D'Cruz, Joseph, and Alan Rugman, 2000. Multinationals as Flagship Firms - Regional Business Networks, Oxford University Press, UK.

Deininger, Klaus and Lyn Squire. 1996. Measuring Income Inequality: A New Database. Harvard Institute for International Development - Development Discussion Paper Series.

Djankov, Simeon, Rafael La Porta, Florencio Lopez-de-Silanes and Andrie Shleifer, 2002, The Regulation of Entry, Quarterly Journal of Economics 117: 1 - 37.

Edison, Hali, Ross Levine, Luca Ricci, and Torsten Slok. 2002. International financial integration and economic growth. Journal of International Money and Finance 21(6) 749.

Faccio, Mara, and Larry Lang, 2002. The Ultimate Ownership in Western European Corporations, Journal of Financial Economics 65(3): 365 - 95.

Fisman, Raymond, 2001. Estimating the Value of Political Connections. American Economic Review 91 (4): 1095 - 102.

Fisman, Raymond, and Jakob Svensson, 2000. Are Corruption and Taxation Really Harmful to Growth? Firm-Level Evidence. Columbia University Working Paper. 
Fisman, Raymond, and Rafael Di Tella, 2001. Are Politicians Really Paid Like Bureaucrats? National Bureau of Economic Research Working Paper 9165.

Frankel, Jeffrey A., 2000. Assessing the Efficiency Gain from Further Liberalization. Conference on Efficiency, Equity and Legitimacy: The Multilateral Trading System at the Millennium (June).

Gerschenkron, Alexander, 1962. Economic Backwardness in Historical Perspective. Harvard University Press.

Glaeser, Edward and Claudia Goldin. 2004. Corruption and Reform: An Introduction. In Edward Glaeser and Claudia Goldin, eds. Corruption and Reform: Lessons from America's History. National Bureau of Economic Research and the University of Chicago Press.

Haber, Stephen, Armando Razo, and Noel Maurer 2003. The Politics of Property Rights: Political Instability, Credible Commitments, and Economic Growth in Mexico, 18761929. Cambridge University Press.

Hall, Robert, and Charles Jones, 1999. Why Do Some Countries Produce So Much More Output Per Worker Than Others? Quarterly Journal of Economics 114 (1): 83-116.

Hayek, Friedrich, 1944. The Road to Serfdom. Chicago: University of Chicago Press.

Hayek, Friedrich, 1960. The Constitution of Liberty. South Bend: Gateway Editions Ltd.

Helpman, Elhanan, Gene M. Grossman, 2002. Interest Groups and Trade Policy, Princeton University Press.

Henry, Peter Blair. 2000a. Do stock market liberalizations cause investment booms? Journal of Financial Economics 58(1/2) 301. 
Henry, Peter Blair. 2000b. Stock market liberalization, economic reform, and emerging market equity prices. Journal of Finance 55(2) 529-62.

Henry, Peter Blair. 2003. Capital-account liberalization, the cost of capital, and economic growth. American Economic Review 93(2) 91.

Holmstrom, Bengt. 1989. Agency costs and innovation. Journal of Economic Behavior and Organizations 12 305-327.

Högfeldt, Peter, 2004. The History and Politics of Corporate Ownership in Sweden, National Bureau of Economic Research Working Paper 10641.

Johnson, Simon, and Todd Mitton, 2003. Cronyism and Capital Controls: Evidence from Malaysia. Journal of Financial Economics 67 (2): 351 - 82.

Jovanovic, Boyan, and Peter L. Rousseau, 2003, General Purpose Technologies, Handbook of Economic Growth, forthcoming.

Khanna, Tarun, and Krishna Palepu, 2000. Is Group Affiliation Profitable in Emerging Markets? An Analysis of Diversified Indian Business Groups, Journal of Finance 55(2): 867-93.

King, Robert, and Ross Levine, 1993. Finance and Growth: Schumpeter Might Be Right. Quarterly Journal of Economics 108(3): 717 - 38.

King, Robert, and Ross Levine, 1994. Capital Fundamentalism, Economic Development, and Economic Growth. Carnegie-Rochester Conference Series on Public Policy 40 (June) 259-92.

Krueger, Anne, 1993. Virtuous and Vicious Circles in Economic Development, American Economic Review 83 (2): 351 - 55.

Krueger, Anne. 1974. The Political Economy of the Rent-Seeking Society. American Economic Review 64 June 291-303. 
La Porta, Rafael, Florencio Lopez-de-Silanes, Andrei Shleifer, and Robert Vishny, 1997a. Legal Determinants of External Finance. Journal of Finance 52(3): 1131 - 51.

La Porta, Rafael, Florencio Lopez-de-Silanes, Andrei Shleifer, and Robert Vishny, 1997b. Trust in Large Organizations, American Economic Review 87(2): 333 - 9.

La Porta, Rafael, Florencio Lopez-de-Silanes, Andrei Shleifer, and Robert Vishny, 1998. Law and Finance. Journal of Political Economy 106 (6): 1113 - 56.

La Porta, Rafael, Florencio Lopez-de- Silanes, and Andrei Shleifer. 1999a. Corporate Ownership Around the World. Journal of Finance 54(2): 471-517.

La Porta, Rafael, Florencio Lopez-de-Silanes, Andrei Shleifer, and Robert Vishny, 1999b. The Quality of Government. Journal of Law, Economics and Organizations 15(1): 222 - 79.

La Porta, Rafael, Florencio Lopez-de-Silanes, Andrei Shleifer, and Robert Vishny, 2000. Government Ownership of Banks. National Bureau of Economic Research Working Paper 7620.

Levine, Ross, 2002. Bank-Based or Market-Based Financial Systems: Which is Better? Journal of Financial Intermediation 11(4): 398 - 428.

Levine, Ross, Asli Demirguc-Kunt and Thorsten Beck. 2003. Law and Finance: Why Does Legal Origin Matter?” Journal of Comparative Economics 31(4) 653-676.

Mankiw, N. Gregory, 1995. The Growth of Nations. Brookings Papers on Economic Activity 1995 (1): $275-310$.

Maurer, Noel and Stephen Haber. 2004. Related Lending and Economic Performance: Evidence from Mexico. Stanford University working paper.

Morck, Randall and Masao Nakamura, 1999. Banks and Corporate Control in Japan. Journal of Finance 54(1): $319-40$. 
Morck, Randall, and Bernard Yeung, 2004. Family Control and the Rent-Seeking Society. Entrepreneurship Theory and Practice 28 (4): 391 - 409.

Morck, Randall, and Lloyd Steier. 2004. The Global History of Corporate Governance - An Introduction. National Bureau of Economic Research working paper.

Morck, Randall, Daniel Wolfenzon, and Bernard Yeung, 2005. Corporate Governance, Economic Entrenchment and Growth. (NBER WP 10692) Journal of Economics Literature, Vol. 43 No. 3 September, 2005, pp. 657-720.

Morck, Randall, David A. Stangeland, and Bernard Yeung, 2000. Inherited Wealth, Corporate Control, and Economic Growth: The Canadian Disease. In R. Morck ed. Concentrated Corporate Ownership. National Bureau of Economic Research Conference Volume. University of Chicago Press.

Morck, Randall, Masao Nakamura, and Anil Shivdasani, 2000. Banks, Ownership Structure, and Firm Value in Japan. Journal of Business 73(4): 539 - 68.

Murphy, Kevin M., Andrei Shleifer, and Robert Vishny. 1991. The Allocation of Talent: Implications for Growth. Quarterly Journal of Economics. May. 503-530.

Murphy, Kevin, Andrei Shleifer, and Robert Vishny, 1993. Why is Rent Seeking So Costly to Growth? American Economic Review 83(2): 409 - 14.

Nelson, Richard, and Sidney Winter, 1982. An Evolutionary Theory of Economic Change, Cambridge: Harvard University Press.

Olson, Mancur Jr. 1963. Rapid Growth as a Destabilizing Force, Journal of Economic History, 23(4): $529-52$.

Olson, Mancur Jr. 1982. The Rise and Decline of Nations. Yale University Press. New Haven. 
Olson, Mancur Jr., 2000. Power and Prosperity: Outgrowing Communist and Capitalist Dictatorships. Basic Books. New York.

Pagano, Marco and Paolo Volpin. 2001. The political economy of finance. Oxford Review of Economic Policy 17(4) 502.

Perotti, Enrico and Paolo Volpin. 2004. Lobbying on Entry. Centre for Economic Policy Research working paper.

Perotti, Enrico and Ernst-Ludwig Von Thadden. 2003. The Political Economy of Bank and Market Dominance. ECGI - Finance Working Paper 21/2003

Rajan, Raghuram, and Luigi Zingales, 2003. The Great Reversals: the Politics of Financial Development in the Twentieth Century, Journal of Financial Economics 69(1): 5-50.

Rajan, Raghuram. 1992. Insiders and Outsiders: The Choice between Informed and Arm'sLength Debt, Journal of Finance 47 (4): 1367 - 400.

Rodriguez, Francisco, and Jeffrey Sachs, 1999, Why Do Resource-Abundant Economies Grow More Slowly, Journal for Economic Growth 4: 277 - 303.

Roe, Mark. 2003. Political Determinants of Corporate Governance. Oxford University Press.

Romer, Paul M 1986. Increasing Returns and Long-Run Growth. Journal of Political Economy. Oct 94(5) 1002-38.

Rosenthal, Jean-Laurent and Naomi Lamoreaux. 2004a. Corporate Governance and the Plight of Minority Shareholders in the United States Before the Great Depression. National Bureau of Economic Research wp 10900.

Rosenthal, Jean-Laurent and Naomi Lamoreaux. 2004b. Legal Regime and Business's Organizational Choice: A Comparison of France and the United States. National Bureau of Economic Research wp10288. 
Sachs, Jeffrey, and Andrew Warner, 1995. Economic Reform and the Process of Global Integration, Brookings Papers on Economic Activity 1995 (I): 1 - 118.

Sachs, Jeffrey, and Andrew Warner, 2001. The Curse of Natural Resources, European Economic Review 45: 827 - 38.

Schumpeter, Joseph, 1912. Theorie der Wirtschaftlichen Entwichlung, Leipzig, Dunker und Humbolt. Translation by R. Opie (1934), The Theory of Economic Development Cambridge Mass: Harvard University Press.

Schumpeter, Joseph, 1939. Business Cycles, New York: McGraw Hill.

Schumpeter, Joseph, 1942. Capitalism, Socialism and Democracy, $3^{\text {rd }}$ edition, New York: Harper \& Bros.

Stigler, George, 1971. The Theory of Economic Regulation. Bell Journal of Economics and Management Science 2: $3-21$.

Stulz, Rene, and Rohan Williamson. 2003. Culture, Openness, and Finance. Journal of Financial Economics 70(3) 313-349.

Tullock, Gordon, 1967. The Welfare Costs of Tariffs, Monopolies, and Theft. Western Economic Journal 5: 224 - 32. 
Table 1 Panel A: Stability Indexes Using Maximally and Minimally Inclusive Lists of Top Ten Businesses

Maximally inclusive lists include all available enterprises. Minimally inclusive lists exclude financial, foreign controlled, and state controlled enterprises. Stability indexes are fractions of top ten 1975 firms still in the 1996 top ten or having grown at least as fast as total GDP, weighted by 1975 employees, $\Omega_{L 75}^{G D P}$, or equally, $\Omega_{E}^{G D P}$.

\begin{tabular}{|c|c|c|c|c|}
\hline & \multicolumn{2}{|c|}{ Maximally Inclusive Top 10 List (I) } & \multicolumn{2}{|c|}{ Minimally Inclusive Top 10 List (V) } \\
\hline & $\Omega_{L 75}^{G D P}$ & $\Omega_{E}^{G D P}$ & $\Omega_{L 75}^{G D P}$ & $\Omega_{E}^{G D P}$ \\
\hline Argentina & 0.31173 & 0.2 & 0.39277 & 0.3 \\
\hline Australia & 0.66851 & 0.6 & 0.73239 & 0.6 \\
\hline Austria & 0.83342 & 0.5 & 0.22772 & 0.2 \\
\hline Belgium & 0.40802 & 0.3 & 0.53091 & 0.5 \\
\hline Bolivia & 0.74855 & 0.3 & 0.27430 & 0.3 \\
\hline Brazil & 0.47057 & 0.5 & 0.29455 & 0.3 \\
\hline Canada & 0.40118 & 0.4 & 0.57342 & 0.4 \\
\hline Chile & 0.43968 & 0.4 & 0.27919 & 0.3 \\
\hline Colombia & 0.28799 & 0.2 & 0.60121 & 0.5 \\
\hline Denmark & 0.56300 & 0.4 & 0.72525 & 0.4 \\
\hline Finland & 0.78035 & 0.7 & 0.57816 & 0.5 \\
\hline France & 0.56400 & 0.4 & 0.55802 & 0.4 \\
\hline Germany & 0.76277 & 0.7 & 0.73497 & 0.7 \\
\hline Greece & 0.38197 & 0.3 & 0.07193 & 0.1 \\
\hline Hong Kong & 0.60582 & 0.3 & 0.60582 & 0.3 \\
\hline India & 0.12107 & 0.1 & 0.56486 & 0.4 \\
\hline Indonesia & 0.31485 & 0.3 & 0.39913 & 0.3 \\
\hline Ireland & 0.45014 & 0.3 & 0.39698 & 0.2 \\
\hline Israel & 0.59483 & 0.6 & 0.74440 & 0.4 \\
\hline Italy & 0.76126 & 0.4 & 0.78853 & 0.3 \\
\hline Japan & 0.72527 & 0.7 & 0.59077 & 0.6 \\
\hline Korea & 0.45119 & 0.5 & 0.34111 & 0.4 \\
\hline Malaysia & 0.07326 & 0.1 & 0.12253 & 0.1 \\
\hline Mexico & 0.76431 & 0.5 & 0.62523 & 0.5 \\
\hline Netherlands & 0.83944 & 0.6 & 0.84228 & 0.6 \\
\hline New Zealand & 0.20476 & 0.2 & 0.24253 & 0.3 \\
\hline Norway & 0.30084 & 0.3 & 0.12190 & 0.1 \\
\hline Pakistan & 0.22827 & 0.2 & 0.45168 & 0.4 \\
\hline Peru & 0.45936 & 0.5 & 0.26775 & 0.2 \\
\hline Philippines & 0.25999 & 0.2 & 0.07253 & 0.1 \\
\hline Portugal & 0.34266 & 0.2 & 0.08388 & 0.1 \\
\hline Singapore & 0.56019 & 0.4 & 0.06400 & 0.1 \\
\hline South Africa & 0.57996 & 0.5 & 0.66960 & 0.6 \\
\hline Spain & 0.46344 & 0.3 & 0.30168 & 0.3 \\
\hline Sri Lanka & 0.07093 & 0.1 & 0.24317 & 0.2 \\
\hline Sweden & 0.78482 & 0.5 & 0.78337 & 0.4 \\
\hline Switzerland & 0.83344 & 0.7 & 0.83344 & 0.7 \\
\hline Taiwan & 0.39190 & 0.2 & 0.62445 & 0.3 \\
\hline Thailand & 0.74212 & 0.6 & 0.60927 & 0.5 \\
\hline Turkey & 0.20833 & 0.1 & 0.38338 & 0.2 \\
\hline United Kingdom & 0.23128 & 0.2 & 0.53862 & 0.4 \\
\hline United States & 0.53122 & 0.5 & 0.53122 & 0.5 \\
\hline Uruguay & 0.49031 & 0.3 & 0.40564 & 0.2 \\
\hline Venezuela & 0.77755 & 0.5 & 0.40070 & 0.4 \\
\hline
\end{tabular}


Table 2: Main Variables

Panel A: Univariate Statistics

\begin{tabular}{|c|c|c|c|c|c|}
\hline Variable & & Mean & $\begin{array}{l}\text { Standard } \\
\text { Deviation }\end{array}$ & Minimum & Maximur \\
\hline \multicolumn{6}{|c|}{ Based on Maximally Inclusive List (I) of Top Ten Firms } \\
\hline $\begin{array}{l}\text { Continued importance index using total GDP } \\
\text { growth as benchmark, labor weighted. }\end{array}$ & $\Omega_{L 75}^{G D P}$ & 0.495 & 0.223 & .0709 & 0.839 \\
\hline $\begin{array}{l}\text { Continued importance index using total GDP } \\
\text { growth as benchmark, equally weighted. }\end{array}$ & $\Omega_{E}^{G D P}$ & 0.381 & 0.179 & 0.100 & 0.727 \\
\hline \multicolumn{6}{|c|}{ Based on Minimally Inclusive List (V) of Top Ten Firms } \\
\hline $\begin{array}{l}\text { Continued importance using total GDP growth } \\
\text { as benchmark, labor weighted. }\end{array}$ & $\Omega_{L 75}^{G D P}$ & 0.460 & 0.227 & .0640 & 0.842 \\
\hline $\begin{array}{l}\text { Continued importance using total GDP growth } \\
\text { as benchmark, equally weighted. }\end{array}$ & $\Omega_{E}^{G D P}$ & 0.354 & 0.166 & .0909 & 0.700 \\
\hline
\end{tabular}

\section{Growth Measures}

\begin{tabular}{|c|c|c|c|c|c|}
\hline $\begin{array}{l}\text { Growth in per capita GDP in US dollars at PPP, } \\
1990 \text { to } 2000\end{array}$ & $\Delta \ln (y)$ & 0.223 & 0.137 & -.0827 & 0.624 \\
\hline Total factor productivity growth, 1990 to 2000 & $\Delta \mathrm{TFP}$ & 0.144 & 0.100 & -.0415 & 0.467 \\
\hline Capital accumulation rate, 1990 to 2000 & $\Delta \ln (k)$ & 0.263 & 0.207 & -0.217 & 0.674 \\
\hline
\end{tabular}

\section{Control Variables}

1990 per capita GDP in thousands of US Dollars at PPP

Average years of total education for adults (age

$$
>25 \text {, as of 1990) }
$$

1990 per capita capital assets in millions of US

Dollars at PPP

\begin{tabular}{l|llll}
$y$ & 12.91 & 7.587 & 1.675 & 26.47 \\
$h$ & 7.053 & 2.415 & 2.290 & 12.00 \\
$k$ & 31.37 & 22.13 & 1.930 & 79.05 \\
$Y$ & 0.542 & 1.075 & .0161 & 6.617
\end{tabular}

1990 total GDP in trillions of US Dollars at PPP

Sample is the 44 countries listed in Table 1. 
Table 2 (Continued)

Panel B: Pearson Correlation Coefficients Between Stability Indexes and Growth Variables.

\begin{tabular}{|c|c|c|c|c|c|}
\hline \multirow[t]{2}{*}{ Index of ... } & & \multicolumn{2}{|c|}{$\begin{array}{l}\text { Maximally Inclusive } \\
\text { Top } 10 \text { List (I) }\end{array}$} & \multicolumn{2}{|c|}{$\begin{array}{l}\text { Minimally Inclusive } \\
\text { Top } 10 \text { List }(\mathrm{V})\end{array}$} \\
\hline & & $\Omega_{L 75}^{G D P}$ & $\Omega_{E}^{G D P}$ & $\Omega_{L 75}^{G D P}$ & $\Omega_{E}^{G D P}$ \\
\hline \multicolumn{6}{|l|}{ Growth Measures } \\
\hline Per capita GDP growth, '90 to '00 & $\Delta \ln (y)$ & $\begin{array}{c}-0.365 \\
(.02)\end{array}$ & $\begin{array}{c}-0.302 \\
(.05)\end{array}$ & $\begin{array}{c}-0.266 \\
(.08)\end{array}$ & $\begin{array}{c}-0.382 \\
(.01)\end{array}$ \\
\hline Total TFP growth, ' 90 to '00 & $\Delta \mathrm{TFP}$ & $\begin{array}{l}-0.309 \\
(.04)\end{array}$ & $\begin{array}{l}-0.250 \\
(.10)\end{array}$ & $\begin{array}{l}-0.290 \\
(.06)\end{array}$ & $\begin{array}{c}-0.391 \\
(.01)\end{array}$ \\
\hline Capital accumulation, ' 90 to '00 & $\Delta \ln (k)$ & $\begin{array}{c}-0.305 \\
(.04)\end{array}$ & $\begin{array}{c}-0.262 \\
(.09)\end{array}$ & $\begin{array}{c}-0.120 \\
(.44)\end{array}$ & $\begin{array}{c}-0.211 \\
(.17)\end{array}$ \\
\hline \multicolumn{6}{|l|}{ Control Variables } \\
\hline log of '90 per capita GDP & $\ln (y)$ & $\begin{array}{l}0.471 \\
(.00)\end{array}$ & $\begin{array}{l}0.482 \\
(.00)\end{array}$ & $\begin{array}{l}0.340 \\
(.02)\end{array}$ & $\begin{array}{l}0.272 \\
(.07)\end{array}$ \\
\hline log of '90 per capita capital & $\ln (k)$ & $\begin{array}{l}0.500 \\
(.00)\end{array}$ & $\begin{array}{l}0.541 \\
(.00)\end{array}$ & $\begin{array}{l}0.271 \\
(.08)\end{array}$ & $\begin{array}{l}0.235 \\
(.12)\end{array}$ \\
\hline $\begin{array}{r}\text { Log of over } 25 \text { pop. av. years of } \\
\text { schooling }\end{array}$ & $\ln (h)$ & $\begin{array}{l}0.324 \\
(.03)\end{array}$ & $\begin{array}{l}0.422 \\
(.00)\end{array}$ & $\begin{array}{l}0.318 \\
(.04)\end{array}$ & $\begin{array}{l}0.285 \\
(.06)\end{array}$ \\
\hline Log of ' 90 total GDP & $\ln (Y)$ & $\begin{array}{l}.0907 \\
(.56)\end{array}$ & $\begin{array}{l}0.244 \\
(.11)\end{array}$ & $\begin{array}{l}0.382 \\
(.01)\end{array}$ & $\begin{array}{l}0.467 \\
(.00)\end{array}$ \\
\hline
\end{tabular}

Samples are countries listed in Table 1. Numbers in parentheses are probability levels for rejecting the null hypothesis of zero correlations coefficients 


\section{Table 3: Regressions of Growth on Corporate Sector Stability Indexes}

OLS regressions of growth on stability and controls. Growth is 1990 to 2000 per capita GDP growth, $\Delta \ln (y)$, total factor productivity growth, $\triangle T F P$, or per capita capital accumulation, $\Delta \ln (k)$. $\Delta T F P$ is $\Delta \ln (y)-0.3 \Delta \ln (k)$. Stability indexes, $\Omega$, measure the proportion of ' 75 top ten firms still in the top ten in ' 96 or growing no slower than GDP from '75 to ' 96 . Control variables are the log of '90 per capita GDP, $\ln (y)$, log of '90 capital assets per capita, $\ln (k)$, and log average years of education for adults, $\ln (h)$. All financial variables are in '96 US dollars at purchasing power parity.

Panel A: Regression with Typical Control Coefficients and Regression Statistics Stability index is equal-weighted and based on lists of top ten domestic private sector firms.

\begin{tabular}{lc|ccc} 
& & \multicolumn{1}{|c}{$\Delta \ln (y)$} & \multicolumn{1}{c}{$\Delta T F P$} & \multicolumn{1}{c}{$\Delta \ln (k)$} \\
\hline Constant & & $0.412(.15)$ & $0.442(.03)$ & \multicolumn{1}{c}{$.0984(.82)$} \\
Continued Importance, equal-weighted. & $\Omega_{E}^{G D P}$ & $-0.373(.00)$ & $-\mathbf{0 . 2 6 9 ( . 0 0 )}$ & $\mathbf{- 0 . 3 4 5 ( . 0 7 )}$ \\
Log of per capita GDP, 1990 & $\ln (y)$ & $.0845(.44)$ & $-.0539(.50)$ & $\mathbf{0 . 4 6 1 ( . 0 1 )}$ \\
Log of average years of education & $\ln (h)$ & $\mathbf{0 . 1 8 9 ( . 0 2 )}$ & $\mathbf{0 . 1 6 0 ( . 0 1 )}$ & $\mathbf{. 0 9 4 2 ( . 4 4 )}$ \\
Log of per capita capital assets, 1990 & $\ln (k)$ & $-0.120(.16)$ & $-.000887(.99)$ & $\mathbf{- 0 . 3 9 6 ( . 0 0 )}$ \\
\hline F-Statistic & $F$ & $\mathbf{3 . 7 7}(.01)$ & $\mathbf{4 . 2 1 ( . 0 1 )}$ & $\mathbf{2 . 9 7 ( . 0 3 )}$ \\
Adjusted R-Squared & $R^{2}$ & 0.205 & 0.230 & 0.155 \\
Sample & $N$ & 44 & 44 & 44 \\
\hline
\end{tabular}

\section{Panel B: Regression Coefficients of Corporate Stability}

Only coefficient estimates on corporate stability are shown. List I includes all available firms; List II includes all firms from List I except financial firms; List III is List I less financial and foreign controlled firms; List IV is List I excluding financial and state controlled firms; List $\mathrm{V}$ is List I excluding financial, foreign controlled and state controlled firms.

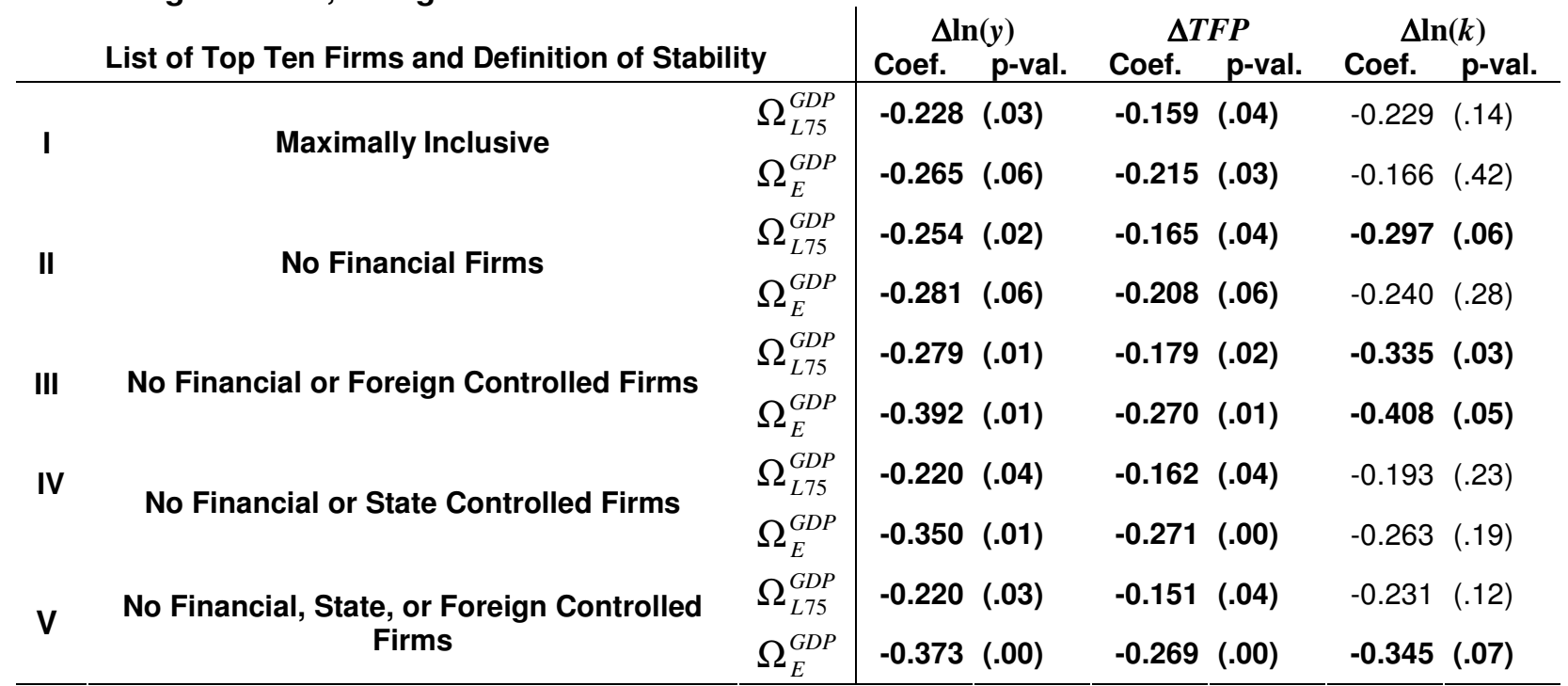

Sample is countries listed in Table 1. Numbers in parentheses are probability levels for rejecting the null hypothesis of zero coefficients. 
Table 4: High and Low Income Countries

OLS regressions of growth on stability and controls. Growth is 1990 to 2000 per capita GDP growth, $\Delta \ln (y)$, total factor productivity growth, $\Delta T F P$, or per capita capital accumulation, $\Delta \ln (k)$. $\Delta T F P$ is $\Delta \ln (y)-0.3 \Delta \ln (k)$. Stability indexes, $\Omega$, measure the proportion of ' 75 top ten firms still in the top ten in ' 96 or growing no slower than GDP from ' 75 to ' 96 . Control variables are the log of '90 per capita GDP, $\ln (y)$, log of '90 capital assets per capita, $\ln (k)$, and log average years of education for adults, $\ln (h)$. All financial variables are in ' 96 US dollars at purchasing power parity. Only coefficient estimates on corporate stability are shown. List I includes all available firms; List II includes all firms from List I except financial firms; List III is List I less financial and foreign controlled firms; List IV is List I excluding financial and state controlled firms; List V is List I excluding financial, foreign controlled and state controlled firms.

\begin{tabular}{|c|c|c|c|c|c|c|c|c|}
\hline \multirow{2}{*}{\multicolumn{3}{|c|}{$\begin{array}{l}\text { Panel A: Coefficients on Corporate Stak } \\
\text { List of Top Ten Firms and Definition of Stability }\end{array}$}} & \multicolumn{2}{|c|}{$\Delta \ln (y)$} & \multicolumn{2}{|c|}{$\triangle T F P$} & \multicolumn{2}{|c|}{$\Delta \ln (k)$} \\
\hline & & & Coef. & p-val. & Coef. & p-val. & Coef. & p-val. \\
\hline \multirow{2}{*}{1} & \multirow{2}{*}{ Maximally Inclusive } & $\Omega_{L 75}^{G D P}$ & -0.102 & $(.43)$ & -.0882 & $(.43)$ & -.0455 & (.73) \\
\hline & & $\Omega_{E}^{G D P}$ & -0.101 & $(.51)$ & -0.108 & $(.42)$ & .0209 & $(.90)$ \\
\hline \multirow{2}{*}{ II } & \multirow{2}{*}{ No Financial Firms } & $\Omega_{L 75}^{G D P}$ & -.0965 & $(.45)$ & -.0768 & $(.49)$ & -.0658 & (.62) \\
\hline & & $\Omega_{E}^{G D P}$ & -.0916 & $(.56)$ & -.0752 & $(.58)$ & -.0547 & $(.74)$ \\
\hline \multirow{2}{*}{ III } & \multirow{2}{*}{$\begin{array}{c}\text { No Financial or Foreign Controlled } \\
\text { Firms }\end{array}$} & $\Omega_{L 75}^{G D P}$ & -0.137 & $(.34)$ & -0.110 & $(.37)$ & -.0890 & $(.54)$ \\
\hline & & $\Omega_{E}^{G D P}$ & -0.158 & $(.39)$ & -0.132 & $(.41)$ & -.0887 & $(.64)$ \\
\hline \multirow{2}{*}{ IV } & \multirow{2}{*}{$\begin{array}{c}\text { No Financial or State Controlled } \\
\text { Firms }\end{array}$} & $\Omega_{L 75}^{G D P}$ & -0.193 & $(.09)$ & -0.159 & $(.10)$ & -0.113 & $(.35)$ \\
\hline & & $\Omega_{E}^{G D P}$ & -0.232 & $(.12)$ & -0.208 & $(.11)$ & -.0800 & (.61) \\
\hline \multirow{2}{*}{ V } & \multirow{2}{*}{$\begin{array}{l}\text { No Financial, State, or Foreign } \\
\text { Controlled Firms }\end{array}$} & $\Omega_{L 75}^{G D P}$ & -0.209 & $(.05)$ & -0.169 & $(.07)$ & -0.134 & $(.24)$ \\
\hline & & $\Omega_{E}^{G D P}$ & -0.315 & $(.04)$ & -0.276 & $(.03)$ & -0.130 & $(.43)$ \\
\hline
\end{tabular}

Sample includes 22 high-income countries: Australia, Austria, Belgium, Canada, Denmark, Finland, France, Germany, Hong Kong, Ireland, Israel, Italy, Japan, Netherlands, New Zealand, Norway, Singapore, Spain, Sweden, Switzerland, United Kingdom, and United States. Numbers in parentheses are probability levels for rejecting the null hypothesis of zero coefficients.

\section{Panel B: Coefficients on Corporate Stability in Low-Income Countries}

\begin{tabular}{|c|c|c|c|c|c|c|c|c|}
\hline \multirow{2}{*}{\multicolumn{3}{|c|}{ List of Top Ten Firms and Definition of Stability }} & \multicolumn{2}{|c|}{$\Delta \ln (y)$} & \multicolumn{2}{|c|}{$\Delta T F P$} & \multicolumn{2}{|c|}{$\Delta \ln (k)$} \\
\hline & & & Coef. & p-val. & Coef. & p-val. & Coef. & p-val. \\
\hline \multirow{2}{*}{$\mathbf{I}$} & \multirow[t]{2}{*}{ Maximally Inclusive } & $\Omega_{L 75}^{G D P}$ & -0.297 & $(.07)$ & -0.190 & $(.06)$ & -0.358 & $(.22)$ \\
\hline & & $\Omega_{E}^{G D P}$ & -0.256 & $(.30)$ & -0.195 & $(.20)$ & -0.203 & $(.64)$ \\
\hline \multirow[b]{2}{*}{ II } & \multirow{2}{*}{ No Financial Firms } & $\Omega_{L 75}^{G D P}$ & -0.382 & $(.02)$ & -0.229 & (.03) & -0.509 & $(.10)$ \\
\hline & & $\Omega_{E}^{G D P}$ & -0.300 & $(.31)$ & -0.209 & $(.26)$ & -0.302 & $(.56)$ \\
\hline \multirow{2}{*}{ III } & \multirow{2}{*}{$\begin{array}{l}\text { No Financial or Foreign } \\
\text { Controlled Firms }\end{array}$} & $\Omega_{L 75}^{G D P}$ & -0.350 & $(.02)$ & -0.205 & $(.03)$ & -0.483 & $(.08)$ \\
\hline & & $\Omega_{E}^{G D P}$ & -0.393 & $(.07)$ & -0.243 & $(.08)$ & -0.501 & $(.20)$ \\
\hline \multirow{2}{*}{ IV } & \multirow{2}{*}{$\begin{array}{c}\text { No Financial or State Controlled } \\
\text { Firms }\end{array}$} & $\Omega_{L 75}^{G D P}$ & -.0563 & $(.81)$ & -.0215 & $(.88)$ & -0.116 & $(.77)$ \\
\hline & & $\Omega_{E}^{G D P}$ & -0.210 & $(.47)$ & -0.139 & $(.45)$ & -0.234 & $(.65)$ \\
\hline \multirow{2}{*}{ V } & \multirow{2}{*}{$\begin{array}{c}\text { No Financial, State, or Foreign } \\
\text { Controlled Firms }\end{array}$} & $\Omega_{L 75}^{G D P}$ & -.0773 & $(.68)$ & -.0150 & $(.90)$ & -0.208 & $(.53)$ \\
\hline & & $\Omega_{E}^{G D P}$ & -0.219 & $(.34)$ & -0.108 & $(.46)$ & -0.369 & $(.36)$ \\
\hline
\end{tabular}

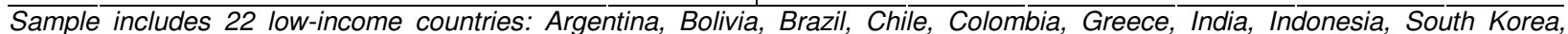
Malaysia, Mexico, Pakistan, Peru, Philippines, Portugal, South Africa, Sri Lanka, Taiwan, Thailand, Turkey, Uruguay, and Venezuela. Numbers in parentheses are probability levels for rejecting the null hypothesis of zero coefficients. 


\section{Table 5: Determinants of Stability}

Regressions are of the form: stability index $=\beta_{0}+\beta_{1}{ }^{*}$ stability determinant $+\beta_{2}{ }^{*} \ln (y)+\beta_{3}{ }^{*} \ln (h)+$ $\beta_{4}{ }^{*} \ln (k)+\varepsilon$. Dependent variables are labor or equal-weighted measures of the proportion of top ten '75 firms that either remain in the top ten list for '96 or grew no slower than GDP from '75 to '96. Control variables are the logs of '75 per capita GDP, capital assets, and average years of education for adults. All financial variables are in 1996 US dollars at purchasing power parity. Only coefficient estimates on political economy variables are shown. List I includes all available firms; List II includes all firms from List I except financial firms; List III is List I less financial and foreign controlled firms; List IV is List I excluding financial and state controlled firms; List V is List I excluding financial, foreign controlled and state controlled firms.

\section{Panel A: Political Economy Variables as Determinants of Stability}

Political economy variables include government size (total final government consumption over GDP in '75), inequality ('75 GINI coefficient), a Common Law legal origin dummy, and red tape (days to obtain legal status as a new business in 1999).

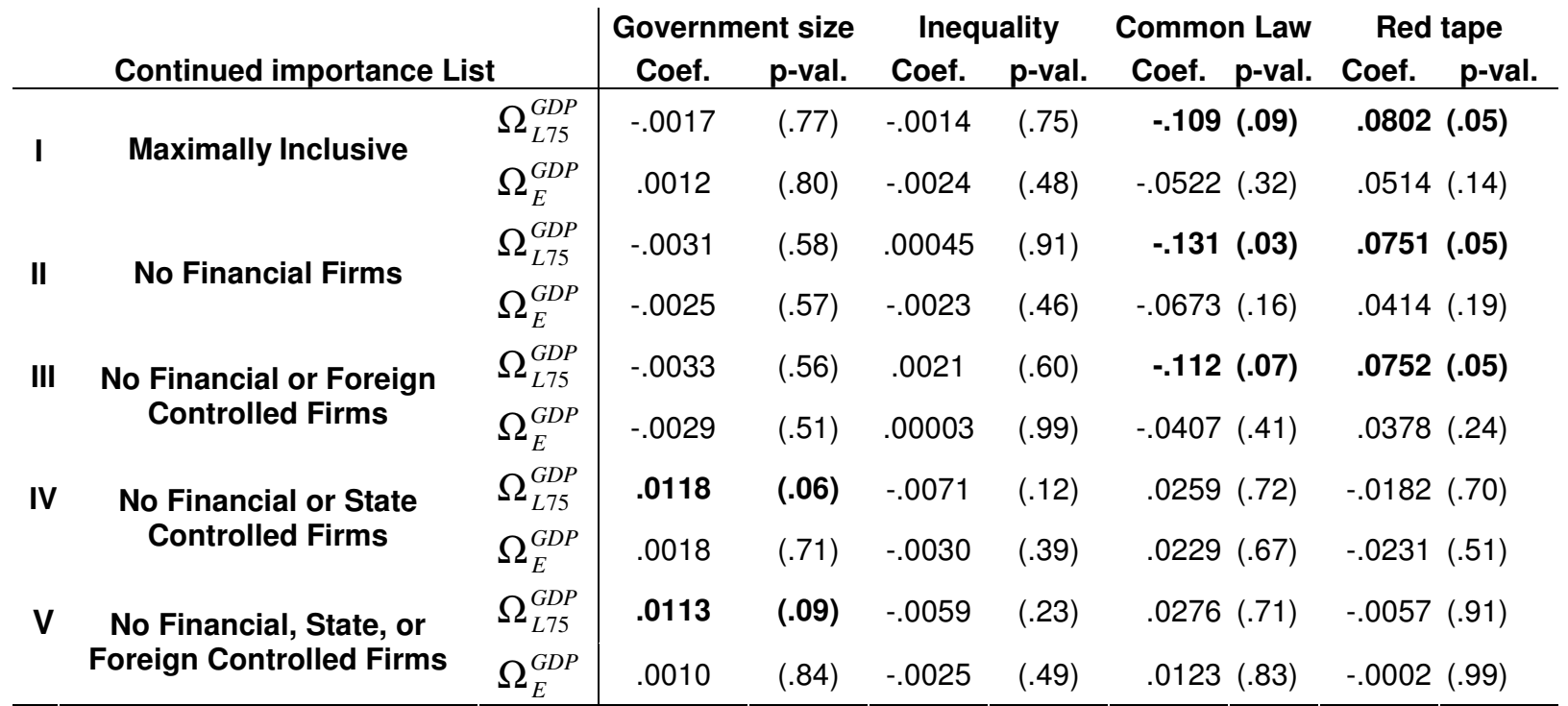

Samples are as listed in Table 1 less Taiwan for government size, and those in Table 1 less Bolivia, Sri Lanka, and Uruguay for red tape delays and costs. Numbers in parentheses are probability levels for rejecting the null hypothesis of zero coefficients. 


\section{Panel B: Financial Development Variables as Determinants of Stability}

Financial development variables include banking system (financial credit to private sector over GDP in 1975), stock market (total market capitalization over GDP in 1978), creditor rights, and shareholder rights, the latter two from La Porta et al. (1997).

\begin{tabular}{|c|c|c|c|c|c|c|c|c|c|c|}
\hline & & & \multicolumn{2}{|c|}{$\begin{array}{c}\text { Banking system } \\
\text { size }\end{array}$} & \multicolumn{2}{|c|}{$\begin{array}{l}\text { Stock market } \\
\text { size }\end{array}$} & \multicolumn{2}{|c|}{$\begin{array}{l}\text { Creditor } \\
\text { rights }\end{array}$} & \multicolumn{2}{|c|}{$\begin{array}{c}\text { Shareholder } \\
\text { rights }\end{array}$} \\
\hline \multicolumn{3}{|c|}{ Continued importance List } & Coef. & p-val. & Coef. & p-val. & Coef. & p-val. & Coef. & p-val. \\
\hline \multirow{2}{*}{ I } & \multirow{2}{*}{ Maximally Inclusive } & $\Omega_{L 75}^{G D P}$ & .00181 & (.22) & -.0338 & $(.70)$ & -.00417 & $(.86)$ & -.0593 & $(.01)$ \\
\hline & & $\Omega_{E}^{G D P}$ & .00224 & $(.04)$ & -.0172 & $(.81)$ & -.00675 & $(.74)$ & -.0337 & $(.07)$ \\
\hline \multirow{2}{*}{ II } & \multirow{2}{*}{ No Financial Firms } & $\Omega_{L 75}^{G D P}$ & .00126 & $(.37)$ & -.0467 & $(.57)$ & -.0141 & $(.54)$ & -.0557 & $(.01)$ \\
\hline & & $\Omega_{E}^{G D P}$ & .00235 & $(.01)$ & -.0173 & $(.79)$ & -.00940 & (.62) & -.0224 & $(.20)$ \\
\hline \multirow{2}{*}{ III } & \multirow{2}{*}{$\begin{array}{l}\text { No Financial or Foreign } \\
\text { Controlled Firms }\end{array}$} & $\Omega_{L 75}^{G D P}$ & .000993 & $(.48)$ & -.0381 & $(.65)$ & -.0119 & $(.60)$ & -.0564 & $(.01)$ \\
\hline & & $\Omega_{E}^{G D P}$ & .00216 & $(.04)$ & -.00279 & $(.97)$ & -.00807 & $(.68)$ & -.0202 & $(.26)$ \\
\hline \multirow{2}{*}{ IV } & \multirow{2}{*}{$\begin{array}{l}\text { No Financial or State } \\
\text { Controlled Firms }\end{array}$} & $\Omega_{L 75}^{G D P}$ & .00215 & $(.18)$ & -.0332 & $(.73)$ & .0272 & $(.32)$ & -.0184 & $(.48)$ \\
\hline & & $\Omega_{E}^{G D P}$ & .00228 & $(.05)$ & .0103 & $(.89)$ & .00792 & $(.71)$ & -.00100 & $(.96)$ \\
\hline \multirow{2}{*}{ V } & \multirow{2}{*}{$\begin{array}{l}\text { No Financial, State, or } \\
\text { Foreign Controlled } \\
\text { Firms }\end{array}$} & $\Omega_{L 75}^{G D P}$ & .00141 & $(.41)$ & -.110 & $(.28)$ & .0142 & $(.63)$ & -.0237 & (.38) \\
\hline & & $\Omega_{E}^{G D P}$ & .00143 & $(.25)$ & -.0592 & $(.44)$ & -0000109 & (.99) & -.0145 & (.48) \\
\hline
\end{tabular}

Samples are as listed in Table 1 less Germany, Hong Kong, Korea, and Taiwan for banking system size, those in Table 1 less Ireland and New Zealand for stock market size, those in Table 1 less Bolivia, Chile, and Venezuela for creditor rights, and those in Table 1 less Bolivia, Chile for shareholder rights. Numbers in parentheses are probability levels for rejecting the null hypothesis of zero coefficients.

\section{Panel C: Openness Variables as Determinants of Stability}

Openness variables include foreign direct investment (FDI inflows as a fraction of GDP in 1975) and trade openness (imports plus exports as fraction of GDP in 1975).

\begin{tabular}{|c|c|c|c|c|c|c|}
\hline \multirow{2}{*}{\multicolumn{3}{|c|}{ Continued importance List }} & \multicolumn{2}{|c|}{ FDI Openness } & \multicolumn{2}{|c|}{ Trade Openness } \\
\hline & & & Coef. & p-val. & Coef. & p-val. \\
\hline \multirow[t]{2}{*}{ I } & \multirow{2}{*}{ Maximally Inclusive } & $\Omega_{L 75}^{G D P}$ & -.00762 & $(.80)$ & .0000513 & $(.94)$ \\
\hline & & $\Omega_{E}^{G D P}$ & -.0162 & $(.44)$ & -.000390 & $(.45)$ \\
\hline \multirow[t]{2}{*}{ II } & \multirow{2}{*}{ No Financial Firms } & $\Omega_{L 75}^{G D P}$ & -.00552 & $(.84)$ & -.000131 & $(.83)$ \\
\hline & & $\Omega_{E}^{G D P}$ & -.0152 & $(.43)$ & -.000490 & $(.30)$ \\
\hline \multirow[t]{2}{*}{ III } & \multirow{2}{*}{ No Financial or Foreign Controlled Firms } & $\Omega_{L 75}^{G D P}$ & -.000575 & $(.98)$ & -.0000882 & $(.89)$ \\
\hline & & $\Omega_{E}^{G D P}$ & -.00224 & $(.91)$ & -.000393 & $(.42)$ \\
\hline \multirow[t]{2}{*}{ IV } & \multirow{2}{*}{ No Financial or State Controlled Firms } & $\Omega_{L 75}^{G D P}$ & -.0533 & $(.07)$ & -.000430 & $(.54)$ \\
\hline & & $\Omega_{E}^{G D P}$ & -.0209 & $(.31)$ & -.000554 & $(.30)$ \\
\hline \multirow[t]{2}{*}{ V } & \multirow{2}{*}{ No Financial, State, or Foreign Controlled Firms } & $\Omega_{L 75}^{G D P}$ & -.0763 & $(.02)$ & -.00107 & $(.15)$ \\
\hline & & $\Omega_{E}^{G D P}$ & -.0429 & $(.05)$ & -.00101 & $(.06)$ \\
\hline
\end{tabular}

Samples are as listed in Table 1 less Germany, Greece, Hong Kong, Japan, Korea, Switzerland and Taiwan for foreign direct investment, and those in Table 1 less Taiwan for trade openness. Numbers in parentheses are probability levels for rejecting the null hypothesis of zero coefficients 


\section{Table 6: Regressions of Growth on Corporate Sector Stability Indexes and Institutional Environment Variables}

OLS regressions of growth on stability, institutional environment, and controls. Growth is 1990 to 2000 per capita GDP growth, $\Delta \ln (y)$, total factor productivity growth, $\Delta T F P$, or per capita capital accumulation, $\Delta \ln (k) . \Delta T F P$ is $\Delta \ln (y)-0.3 \Delta \ln (k)$. Stability indexes, $\Omega$, measure the proportion of ' 75 top ten firms still in the top ten in ' 96 or growing no slower than GDP from ' 75 to ' 96 . Panel A uses stability based on List I, which includes all available firms. Panel B uses stability based on List V, which is List I excluding financial, foreign controlled and state controlled firms. Institution variables include a Common Law legal origin dummy, red tape (days to obtain legal status as a new business in 1999), government size (total final government consumption over GDP in '75), banking system (financial credit to private sector over GDP in 1975), and trade openness (imports plus exports as fraction of GDP in 1975). Control variables are the log of ' 90 per capita GDP, In( $(y)$, log of ' 90 capital assets per capita, $\ln (k)$, and log average years of education for adults, $\ln (h)$. All financial variables are in ' 96 US dollars at purchasing power parity.

Panel A. Stability based on List I - Maximally inclusive top ten lists of leading businesses including financial, foreign controlled, and sometime state controlled firms

Per capita GDP growth, $\Delta \ln (y) \quad$ Productivity growth, $\triangle T F P$

Capital accumulation, $\Delta \ln (k)$

\begin{tabular}{|c|c|c|c|c|c|c|c|c|c|c|c|c|c|c|c|c|c|}
\hline $\begin{array}{l}\text { stability, } \\
\text { value-wtd }\end{array}$ & $\begin{array}{l}-.204 \\
(.06)\end{array}$ & $\begin{array}{l}-.253 \\
(.02)\end{array}$ & $\begin{array}{l}-.222 \\
(.04)\end{array}$ & $\begin{array}{l}-.202 \\
(.06)\end{array}$ & $\begin{array}{l}-.212 \\
(.04)\end{array}$ & $\begin{array}{l}-.214 \\
(.05)\end{array}$ & $\begin{array}{l}-.141 \\
(.08)\end{array}$ & $\begin{array}{l}-.170 \\
(.03)\end{array}$ & $\begin{array}{l}-.154 \\
(.05)\end{array}$ & 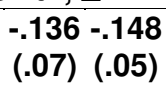 & $\begin{array}{l}-.142 \\
(.07)\end{array}$ & $\begin{array}{l}-.211 \\
(.20)\end{array}$ & $\begin{array}{l}-.275 \\
(.09)\end{array}$ & $\begin{array}{l}-.226 \\
(.15)\end{array}$ & $\begin{array}{l}-.219 \\
(.17)\end{array}$ & $\begin{array}{l}-.213 \\
(.17)\end{array}$ & $\begin{array}{l}-.238 \\
(.15)\end{array}$ \\
\hline $\begin{array}{l}\text { common } \\
\text { law }\end{array}$ & $\begin{array}{l}.027 \\
(.54)\end{array}$ & & & & & $\begin{array}{l}.061 \\
(.30)\end{array}$ & $\begin{array}{l}.019 \\
(.54)\end{array}$ & & & & $\begin{array}{l}.041 \\
(.34)\end{array}$ & $\begin{array}{l}.024 \\
(.72)\end{array}$ & & & & & $\begin{array}{l}.067 \\
(.46)\end{array}$ \\
\hline red tape & & $\begin{array}{l}.029 \\
(.28)\end{array}$ & & & & $\begin{array}{l}.059 \\
(.09)\end{array}$ & & $\begin{array}{l}.016 \\
(.44)\end{array}$ & & & $\begin{array}{l}.037 \\
(.15)\end{array}$ & & $\begin{array}{l}.046 \\
(.26)\end{array}$ & & & & $\begin{array}{l}.076 \\
(.16)\end{array}$ \\
\hline gov't size & & & $\begin{array}{l}.000 \\
(.98)\end{array}$ & & & $\begin{array}{l}-.001 \\
(.72)\end{array}$ & & & $\begin{array}{l}.000 \\
(.87)\end{array}$ & & $\begin{array}{l}-.001 \\
(.85)\end{array}$ & & & $\begin{array}{l}-.002 \\
(.74)\end{array}$ & & & $\begin{array}{l}-.003 \\
(.63)\end{array}$ \\
\hline $\begin{array}{l}\text { banking } \\
\text { dev. }\end{array}$ & & & & $\begin{array}{l}.001 \\
(.23)\end{array}$ & & $\begin{array}{l}-.001 \\
(.23)\end{array}$ & & & & $\begin{array}{l}-.001 \\
(.14)\end{array}$ & $\begin{array}{r}-.001 \\
(.15)\end{array}$ & & & & $\begin{array}{l}-.001 \\
(.75)\end{array}$ & & $\begin{array}{l}-.001 \\
(.75)\end{array}$ \\
\hline $\begin{array}{l}\text { trade } \\
\text { openness }\end{array}$ & & & & & $\begin{array}{l}.001 \\
(.08)\end{array}$ & $\begin{array}{l}.000 \\
(.32)\end{array}$ & & & & $\begin{array}{l}.000 \\
(.16)\end{array}$ & $\begin{array}{l}.000 \\
(.52)\end{array}$ & & & & & $\begin{array}{l}.001 \\
(.11)\end{array}$ & $\begin{array}{l}.00 \\
(.26\end{array}$ \\
\hline
\end{tabular}

Per capita GDP growth, $\Delta \ln (y) \quad$ Productivity growth, $\Delta T F P \quad$ Capital accumulation, $\Delta \ln (k)$

\begin{tabular}{|c|c|c|c|c|c|c|c|c|c|c|c|c|c|}
\hline $\begin{array}{l}\text { stability, } \\
\text { equal wtd. }\end{array}$ & $\begin{array}{rr}-.238 & -.265 \\
(.09) & (.06)\end{array}$ & $\begin{array}{l}-.256 \\
(.07)\end{array}$ & $\begin{array}{l}-.214 \\
(.13)\end{array}$ & $\begin{array}{l}-.216 \\
(.12)\end{array}$ & $\begin{array}{r}-.197 \\
(.18)\end{array}$ & $\begin{array}{l}-.194 \\
(.05)\end{array}$ & $\begin{array}{cc}-.211 & -.209 \\
(.04) & (.04)\end{array}$ & $\begin{array}{r}-.172 \\
(.09)(.06)\end{array}$ & $\begin{array}{l}-.167 \\
(.11)\end{array}$ & \begin{tabular}{|cc}
-.146 & -.182 \\
$(.49)$ & $(.39)$
\end{tabular} & $\begin{array}{l}-.154 \\
(.47)\end{array}$ & 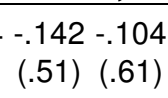 & $\begin{array}{l}-.100 \\
(.65)\end{array}$ \\
\hline $\begin{array}{l}\text { common } \\
\text { law }\end{array}$ & $\begin{array}{l}.041 \\
(.34)\end{array}$ & & & & $\begin{array}{l}.078 \\
(.19)\end{array}$ & $\begin{array}{l}.028 \\
(.35)\end{array}$ & & & $\begin{array}{l}.052 \\
(.23)\end{array}$ & $\begin{array}{l}.043 \\
(.51)\end{array}$ & & & $\begin{array}{l}.088 \\
(.34)\end{array}$ \\
\hline red tape & $\begin{array}{l}.019 \\
(.49)\end{array}$ & & & & $\begin{array}{l}.056 \\
(.12)\end{array}$ & & $\begin{array}{l}.009 \\
(.63)\end{array}$ & & $\begin{array}{l}.035 \\
(.18)\end{array}$ & $\begin{array}{l}.032 \\
(.44)\end{array}$ & & & $\begin{array}{l}.070 \\
(.21)\end{array}$ \\
\hline gov't size & & $\begin{array}{l}.001 \\
(.87)\end{array}$ & & & $\begin{array}{l}-.001 \\
(.80)\end{array}$ & & $\begin{array}{l}.001 \\
(.69)\end{array}$ & & $\begin{array}{l}.000 \\
(.96)\end{array}$ & & $\begin{array}{r}-.001 \\
(.80)\end{array}$ & & $\begin{array}{l}-.003 \\
(.63)\end{array}$ \\
\hline $\begin{array}{l}\text { banking } \\
\text { dev. }\end{array}$ & & & $\begin{array}{l}-.001 \\
(.29)\end{array}$ & & $\begin{array}{l}-.001 \\
(.28)\end{array}$ & & & $\begin{array}{l}-.001 \\
(.20)\end{array}$ & $\begin{array}{l}-.001 \\
(.21)\end{array}$ & & & $\begin{array}{l}-.001 \\
(.72)\end{array}$ & $\begin{array}{l}-.001 \\
(.71)\end{array}$ \\
\hline $\begin{array}{l}\text { trade } \\
\text { openness }\end{array}$ & & & & $\begin{array}{l}.001 \\
(.13)\end{array}$ & $\begin{array}{l}.000 \\
(.47)\end{array}$ & & & $\begin{array}{l}.000 \\
(.25)\end{array}$ & $\begin{array}{l}.000 \\
(.71)\end{array}$ & & & $\begin{array}{l}.001 \\
(.12)\end{array}$ & $\begin{array}{l}.001 \\
(.33)\end{array}$ \\
\hline
\end{tabular}


Table 6: Regressions of Growth on Corporate Sector Stability Indexes and Institutional Environment Variables (continued)

Panel B. Stability based on List V - Minimally inclusive top ten lists - including only private sector non-financial domestically controlled businesses.

Per capita GDP growth, $\Delta \ln (y) \quad$ Productivity growth, $\triangle T F P \quad$ Capital accumulation, $\Delta \ln (k)$

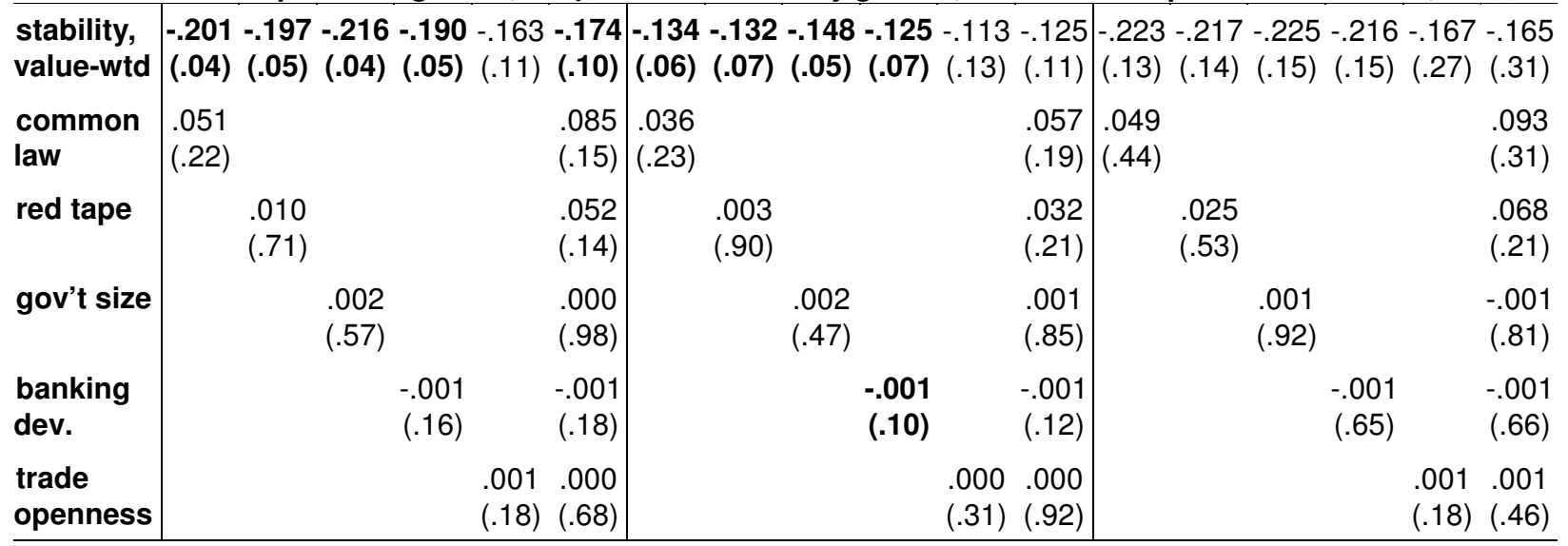

Per capita GDP growth, $\Delta \ln (y) \quad$ Productivity growth, $\Delta T F P \quad$ Capital accumulation, $\Delta \ln (k)$

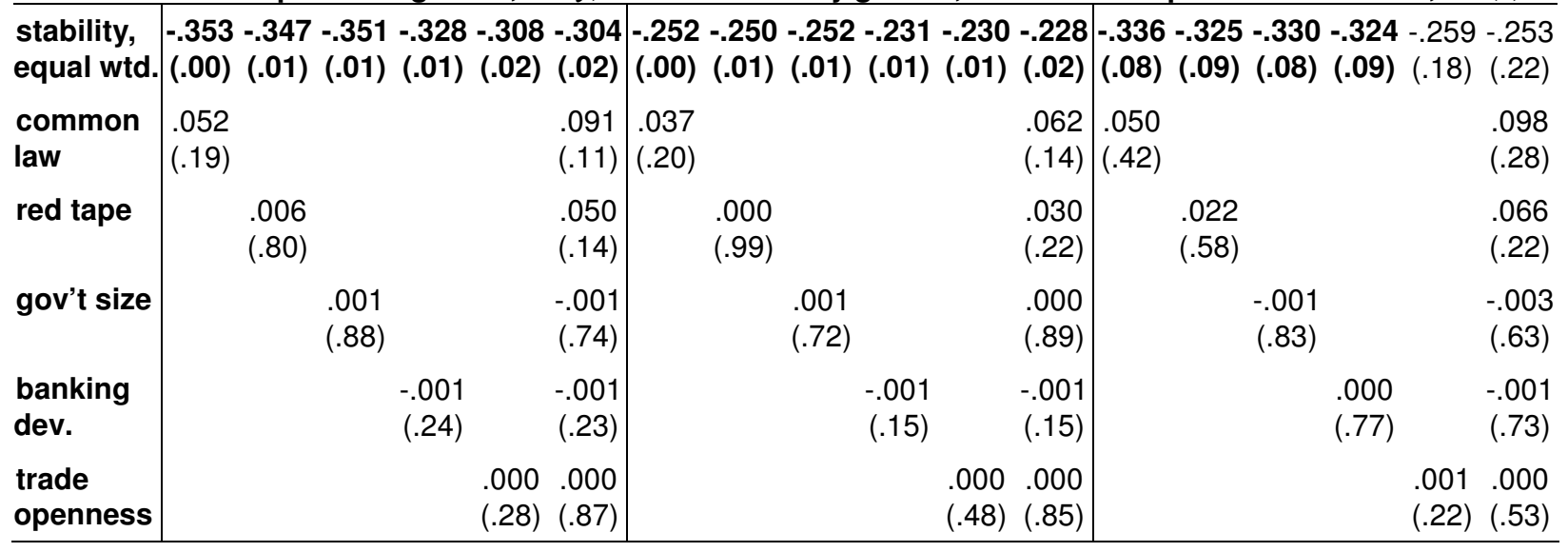

